\title{
Geological records of the recent past, a key to the near future world environments
}

\author{
1 MMSH-LAPMO, BP647, 13094 Aix-en-Provence, Cedex 2, France, e-mail: npm@mmsh.univ-aix.fr \\ 2 Commission for the Geological Map of the World, 77 rue Claude-Bernard-75005, Paris, France, e-mail: ccgm@ club-internet.fr \\ 3 See page 246 .
}

The present paper reproduces with some minor modifications the text of the explanatory notes that accompany a set of two maps co-published in 1999 by the Commission for the Geological Map of the World and ANDRA entitled: Maps of the World Environment during the last two Climatic Extremes (1. The Last Glacial Maximum - ca 18,000 $\pm 2,000$ yrs B.P., 2. The Holocene Optimum - ca 8,000 $\pm 1,000$ yrs B.P.). A reduced version of these two maps, originally printed at the scale of 1:25,000,000, each one in two sheets, is presented here. They propose a reconstruction of the paleoenvironments of the world at two important moments of the recent past climatic evolution and provide useful geological data for refining climatic models and examining, from different angles, the evolution concerning the regions and sites under study.

\section{Introduction}

\section{(by Nicole Petit-Maire and Philippe Bouysse)}

The socio-economic structures of the modern world rest for a large part on the present-day climate of the Earth. Rainfall, temperatures, winds, cloudiness have an influence on the location and characteristics of the vegetal cover, the type of habitats, the agricultural and marine resources, as well as on the life styles of local populations. Any climatic change has impending geopolitical repercussions.

The natural future of our planet, controlled by the fluctuations of Earth's orbital parameters, tends towards a slow, irregular cooling that leads us to a new glacial phase which should reach its maximum in 100,000 years from now. However, the time-scale of this natural trend is not of the same order as the scale that governs the activities of modern mankind. This natural trend cannot contradict the warming resulting from the activities of human beings that are "explosively" increasing into a growing number of ever-voracious consumers of energy, the main sources of which (hydrocarbons and coal) pollute the atmosphere with radiative gases.

This increase in the natural greenhouse effect (which already enhanced by $33^{\circ} \mathrm{C}$ the temperature of our planet) due to the release into the atmosphere of gases such as carbon dioxide $\left(\mathrm{CO}_{2}\right)$ and methane $\left(\mathrm{CH}_{4}\right)$, should bring about within a few decades, a situation where the average temperature of the surface of the Earth could be at least $2^{\circ} \mathrm{C}$ more than nowadays, i.e. the same temperature as determined for the last Climatic Optimum of the present Interglacial (Holocene).

It is therefore of paramount importance to try to foresee which modifications of our environment these two possible futures, one distant, the other nearer to us, would generate.
Two methods allow a reconstruction of past and future environment as determined by past climatic evolution:

- the theoretical models based on physical laws. These simulations imply a wide space/time grid and present a high margin of uncertainty, due to the complexity and number of interacting elements; they can hardly take into account the great geographical diversity of the continents and the regional effects that it brings about;

- the reconstruction as precise as possible of real situations of past scenarios, corresponding to known differences in global temperature, in relation to the present-day situation. The analysis of multidisciplinary data, datable and stored in the sedimentary strata or in the morphology of the recent Quaternary, can disclose the characteristics of the paleoenvironments created by situations warmer or cooler than today, and in particular, by those corresponding to their extremes, thus defining the recent natural variability of the Earth's landscapes.

The latter was the method adopted when we decided to undertake the realization, under the aegis of the CGMW and with the financial support of ANDRA, of this set of maps aimed at providing a synthetic view of the global paleoenvironments during the last two climatic extremes.

The time slices (supplied in non-calibrated B.P. ages) considered in this work are:

1. The Last Glacial Maximum at ca. 18,000 $\pm 2,000$ years B.P., corresponding to an average temperature on the Earth's surface of about $4.5^{\circ} \mathrm{C}$ lower than nowadays.

2. The Holocene Climatic Optimum at ca. $8,000 \pm 1,000$ years B.P., corresponding to an average global temperature of about $2^{\circ} \mathrm{C}$ higher than nowadays.

From the beginning, the conception of the maps raised the problem of choices to be made due to the lack of synchronicity between the evolution of certain represented environmental parameters, besides the fact that the dating method and the resolution reached varied according to authors. Among the most critical choices to be made was the period of time describing both climatic extremes, and, in particular, that of the Holocene: for the cryologists and marine geologists, it is situated at around 6,000 years B.P. and corresponds to the end of the ice-melting and to the final phase of sea level rise. On the other hand, in climate terms, the reactions of the atmospheric circulation to the astronomical forcing at around 9,000 $\pm 1,000$ years B.P. (Prell and Kutzbach, 1987) appeared as early as 9,500 years B.P. and had been considerably attenuated from ca. 7,200-7,000 years B.P. (Sirocko et al., 1993; Meese et al., 1994; Petit-Maire and Guo, 1996; Pachur and Altmann, 1997; Karlen, 1998). For this reason the data appearing on these CLIMEX (abbreviation for CLIMatic EXtremes) maps correspond to the strongest signals recorded within the time slice chosen; those signals, however, are not necessarily simultaneous.

It is also important to underline that the validity and the density of the data used are far from being homogeneous, and that, for some geographical areas, and for some periods, a unanimous agreement between the experts participating was not reached, as was the case for the extension of the Amazon forest. Very often, only a few cores 
or discontinuous surficial observations were available for the mapping of vast regions. As an example, the vegetal cover of Central Africa is known only through a limited number of samples. As a consequence, the only choice left for the different thematic authors, in the present state of knowledge, was to come to a decision and, sometimes, daringly launch into logical extrapolations.

The following abbreviations will appear in the text:

- LGM for Last Glacial Maximum or Last Pleniglacial.

- HOP for Holocene Optimum, Altithermal or Holocene Hypsithermal.

- SSTs for Sea Surface Temperatures.

\section{Sea surface temperatures}

\section{(by Uwe Pflaumann, Michael Sarnthein, and Hartmut Schulz)}

In a pioneer approach, CLIMAP (Climate Long-range Investigation and Mapping Program) presented for the first time global distribution maps of seasonal sea-surface temperatures (SSTs) during Last Glacial Maximum (LGM) at "18,000 ${ }^{14} \mathrm{C}$ years" (CLIMAP Project Members, 1981). The glacial SSTs estimates were based on census data of various microfossil assemblages from deep-sea sediment cores, census data that were calibrated to the SSTs of modern surface water via a set of transfer functions based on principal component analysis (CABFAC) and a multiple regression approach (Imbrie \& Kipp, 1971; Kipp, 1976). Over the last 20 years, the CLIMAP-LGM temperature maps provided valuable boundary conditions for a number of numerical models that simulate past climates and, vice versa, for testing the quality of ocean general circulation models to predict future climate.

In the tropics the glacial-to-interglacial SSTs anomalies of CLIMAP only amount to $-2( \pm 1.5)^{\circ} \mathrm{C}$, in upwelling regions they may exceed $-4^{\circ} \mathrm{C}$. However, as summarized by Anderson and Webb (1994), these anomalies do not fit the various land-based paleotemperature data deduced from strongly lowered snowlines (Bowler et al., 1976) and the major vegetation changes in the tropics (Frenzel et al., 1992; Rind and Peteet, 1985), nor the marine SSTs records from $\mathrm{Sr} / \mathrm{Ca}$ and $\delta^{18} \mathrm{O}$ ratios in corals off Barbados, which result into SSTs anomalies of $-5( \pm 0.5)^{\circ} \mathrm{C}$ (Guilderson et al., 1994).

Likewise, the extremely low glacial SSTs and seasonally persistent sea-ice coverage of the Greenland-Icelandic-Norwegian Seas, as proposed by CLIMAP (1981), remained controversial, when compared with the microfossil and stable isotopic records (Hebbeln et al., 1994; Sarnthein, 1995; Weinelt et al., 1996).

To constrain more precisely the actual range of glacial-to-interglacial SSTs variations in the ocean we present a new dataset of seasonal SSTs during the LGM, estimated at 70 sites in the equatorial, southeastern, and northeastern Atlantic. Our approach is based (1) on more precise age definitions and age control, (2) on a different transfer technique, the Modern Analog Technique (MAT), (3) on an improved calibration of the microfaunal census data to modern SSTs, using 738 modern core-top samples from the Atlantic and the "objectively analyzed" hydrographic dataset of Levitus (1982).

We have also shown on the LGM map, the SSTs values (only for northern Winter/southern Summer) off Australia and Eastern Asia.

Moreover, we present a new SSTs dataset of the early Holocene climatic optimum in the Atlantic Ocean and Arabian Sea, during a time slice centered near the maximum of insulation on the northern hemisphere, i.e. about 9,000 $\pm 1,000{ }^{14} \mathrm{C}$ years ago (Prell and Kutzbach, 1987) representing contrasting climatic boundary conditions to the LGM, along with large scale environmental changes in the transition zones between the humid tropical and the arid to semiarid zones in northern Africa, India and east Asia (Petit-Maire, 1990; Petit-Maire et al. 1995)

We will not describe at large, here, the precise analytical methods used in the reconstruction of the paleotemperature isolines:
AMS ${ }^{14} \mathrm{C}$ ages, medium to high resolution planktonic and/or benthic $\delta^{18} \mathrm{O}$ stratigraphy, use of the most appropriate sedimentation rates, statistical processing, ... (cf. e.g. Pflaumann et al., 1996).

For reconstructing the LGM Atlantic SSTs, we used about 50 sediment cores from the Kiel and Bordeaux/Gif collections. Moreover, we resampled and/or re-evaluated about 20 CLIMAP cores.

The reconstruction of early Holocene SSTs was based on 92 cores from the Atlantic and 35 cores from the Arabian Sea from the Kiel, Bordeaux/Gif, and Lamont core collections.

The northern Winter/southern Summer SSTs correspond to the February-April interval, those of the northern Summer/southern Winter to the August-October interval.

The complete dataset is available via world wide web from the German paleoclimate data repository PANGAEA: www.pangaea.de/ftp/Pflaumann.

\section{Last Glacial Maximum}

Our reconstruction of the Atlantic SSTs at the LGM confirms the number of features different from today which were already recognized by the CLIMAP reconstructions, such as (1) the expansion of polar water with a consequent southeastward shift of the Polar Front near $45^{\circ} \mathrm{N}$; (2) an extensive subtropical region with a stable high SSTs level, hence (3) a strong compression of the northern temperate climate zone into a small zonal belt with a steep SSTs gradient. However, our new reconstruction also differs markedly from the CLIMAP SSTs pattern in several prominent structures:

- Based on well substantiated and consistent data arrays, the glacial SSTs reach $3.5-4.5^{\circ} \mathrm{C}$ in large parts of the Nordic Seas $\left(50-80^{\circ} \mathrm{N}\right)$ during the summer. This temperature range precludes the perennial sea-ice cover postulated by CLIMAP. Only during the winter, our new SSTs pattern closely reflects the extensive sea-ice cover down to about $50^{\circ} \mathrm{N}$, as outlined by CLIMAP. Contrary to CLIMAP, the open-sea conditions in high latitudes during the glacial summer have led to an increased seasonality and deepwater formation (Weinelt et al., 1996), and, which is especially striking, to an enhanced heat flux to high latitudes, and accordingly, to an additional flux of atmospheric moisture to northern Europe, here strongly promoting the build-up of ice sheets.

- In the northeastern Atlantic, at $45-60^{\circ} \mathrm{N}$, the SIMMAX-SSTs contours indicate a hitherto unknown warm-water advection to the northeastern central Atlantic, implying a small anticyclonic gyre west of Ireland during both summer and winter.

- The zonal SSTs anomalies, linked to upwelling along the northwest coast of Africa at the LGM, are much less pronounced than shown in the CLIMAP reconstruction. In contrast, the SSTs anomalies precisely agree with the CLIMAP values in the upwelling region off Southwest Africa.

- Different from CLIMAP we find a strong modern-to-glacial cooling near the equator, reaching $5^{\circ}-8^{\circ} \mathrm{C}$ (instead of $4^{\circ} \mathrm{C}$ ) during the northern summer and $6.5^{\circ} \mathrm{C}$ (instead of $0^{\circ}-2^{\circ} \mathrm{C}$ ) during the northern winter, in harmony with the land and coral records outlined above (Bowler et al., 1976; Rind and Peteet, 1985; Frenzel et al., 1992; Guilderson et al., 1994; Anderson and Webb, 1994). This cooling implies a strongly reduced evaporation and, accordingly, a reduced moisture transport to the encompassing tropical and subtropical continents, during the LGM. The resulting glacial continental aridity is well documented in terrestrial sediment records both from land and from the deep sea (Sarnthein, 1978; Sarnthein et al., 1982; Talbot, 1984).

On account of these differences, we did not merge our new SSTs estimates with the CLIMAP estimates, into joint maps of LGM and SSTs in the world ocean.

\section{Holocene Climatic Optimum}

In general, the early Holocene SSTs estimates from the Atlantic and Arabian Sea closely resemble the modern distribution SSTs patterns for both winter and summer, with deviations hardly exceeding 


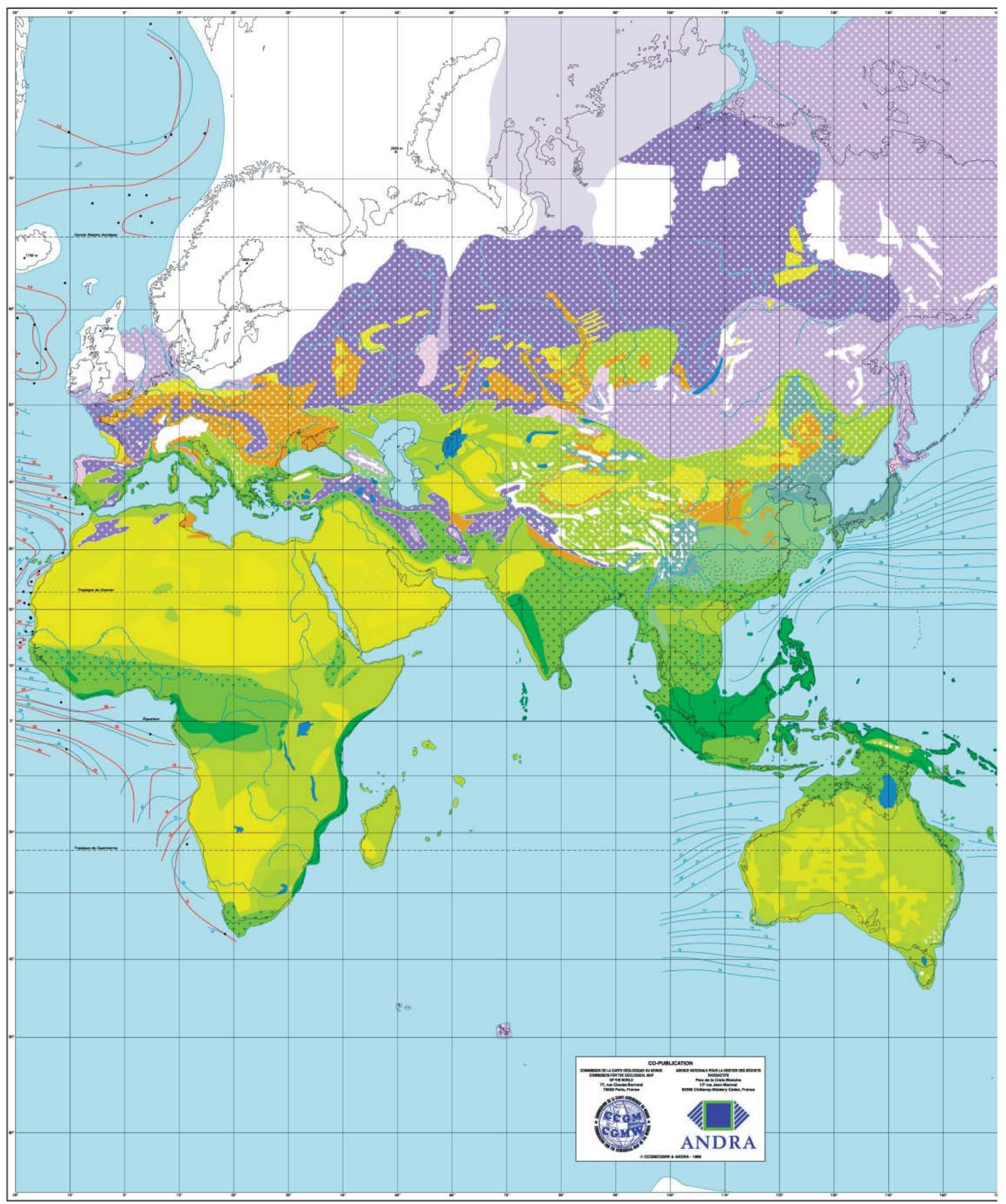

Map 1 The Last Glacial Maximum (8,000 $\pm 1,000$ years, B.P.). Average global temperature: $2^{\circ} \mathrm{C}$ higher than nowadays.

$\square$ Arctic or alpine tundra

Steppe tundra

$\square$ Taiga

$\square$ Boreal forest (southern taiga) $\square$ Mixed temperate forest

Decidual temperate forest

$\square$ Xerophytic or Mediterranean woodland

$\square$ Steppe $\square$ Savanna

Wooded steppe or wooded savanna

Tropical or equatorial forest

$\square$ Arid area
Mangrove

$\square$ Loess (active deposition)

$\square$ Sand / Dune field (active deposition)

- Permanent or seasonal lake 


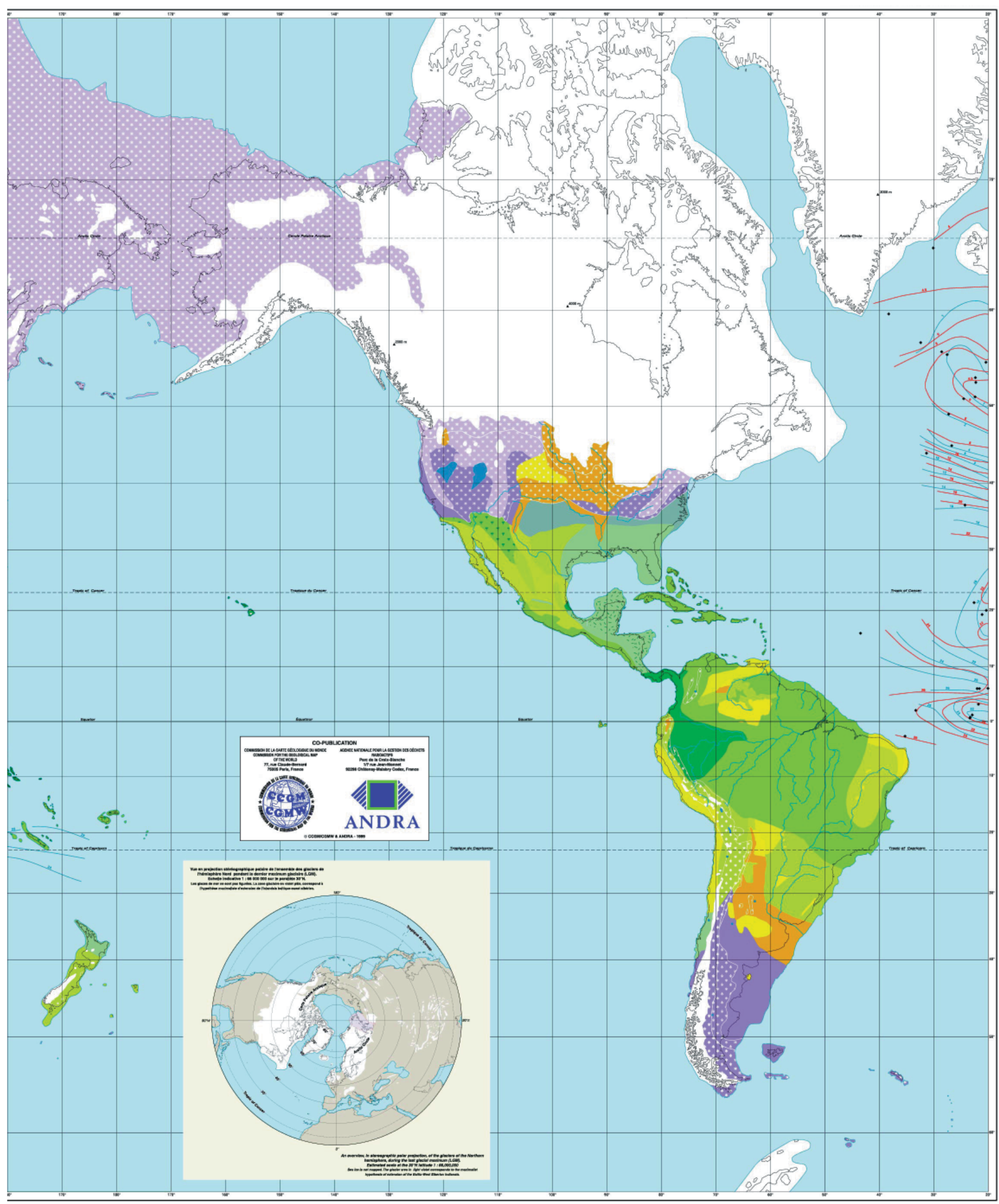

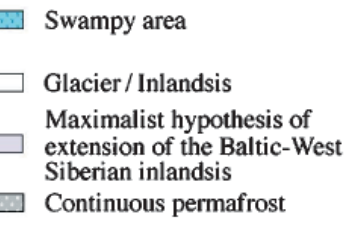

Swampy area
Maximalist hypothesis of extension of the Baltic-West

Continuous permafrost

$\square$ Discontinuous permafrost
$\square$ Ocean or closed sea
- Core
$-\quad$ Inlandsis height

Discontinuous permafrost

\begin{abstract}
Northern summer/Southern winter
Sea Surface Temperature
Northern winter/Southern summer Sea Surface Temperature
\end{abstract}

Present-day shoreline

$\sim$ River 


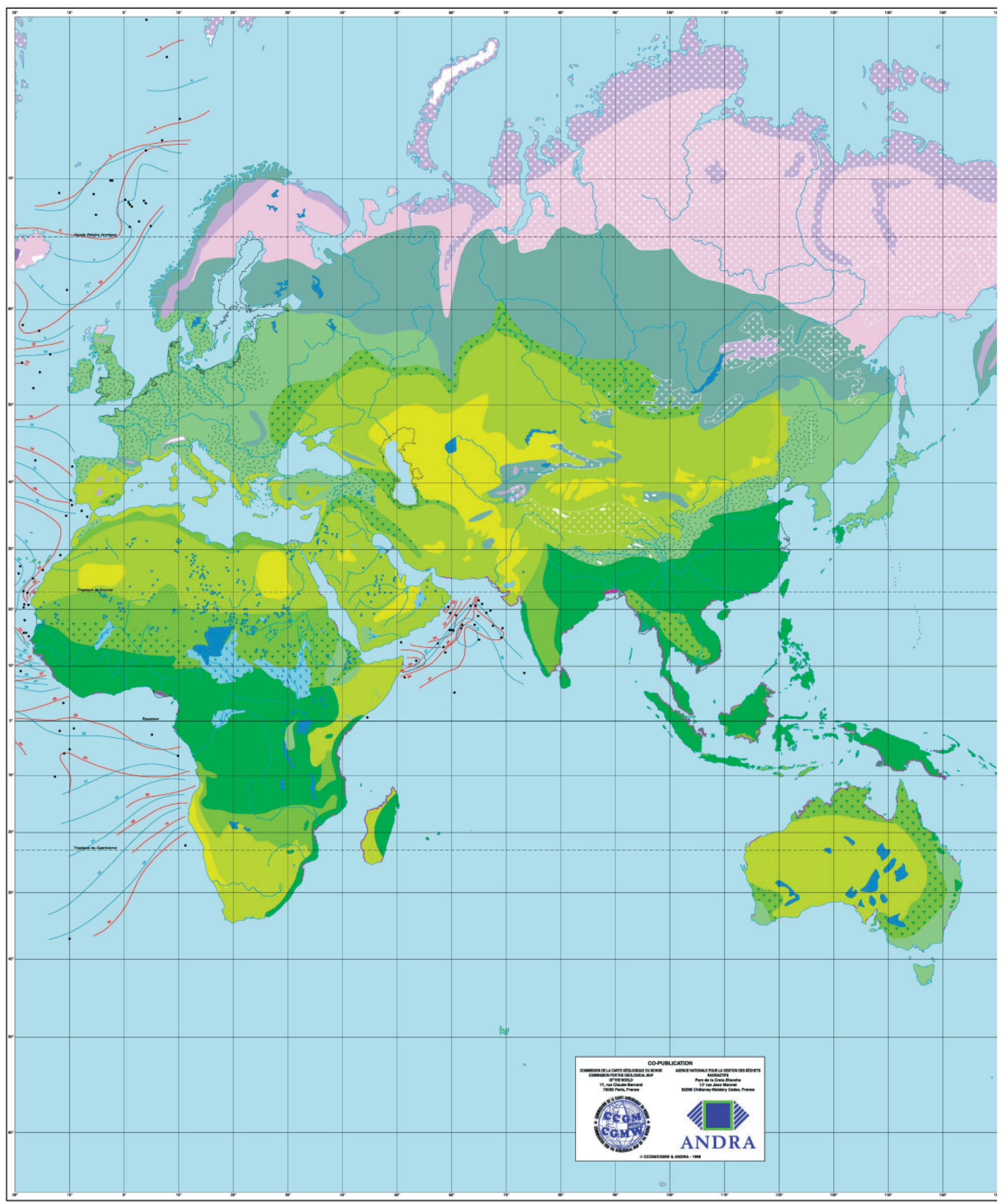

Map 2 The Holocene Optimum (8,000 $\pm 1,000$ years, B.P.). Average global temperature: ${ }^{2} \mathrm{C}$ higher than nowadays.
$\square$ Arctic or alpine tundra
$\square$ Mixed temperate forest
$\square \quad$ Savanna
Mangrove
$\square$ Steppe tundra
$\square$ Decidual temperate forest
$\square$ Taiga
Xerophytic or Mediterranean woodland
Wooded steppe or wooded savanna
$\square$ Tropical or equatorial forest
$\square$ Loess (active deposition)
$\square$ Boreal forest (southern taiga)
$\square$ Steppe
$\square$ Arid area
Sand/Dune field
(active deposition)
- Permanent or seasonal lake 


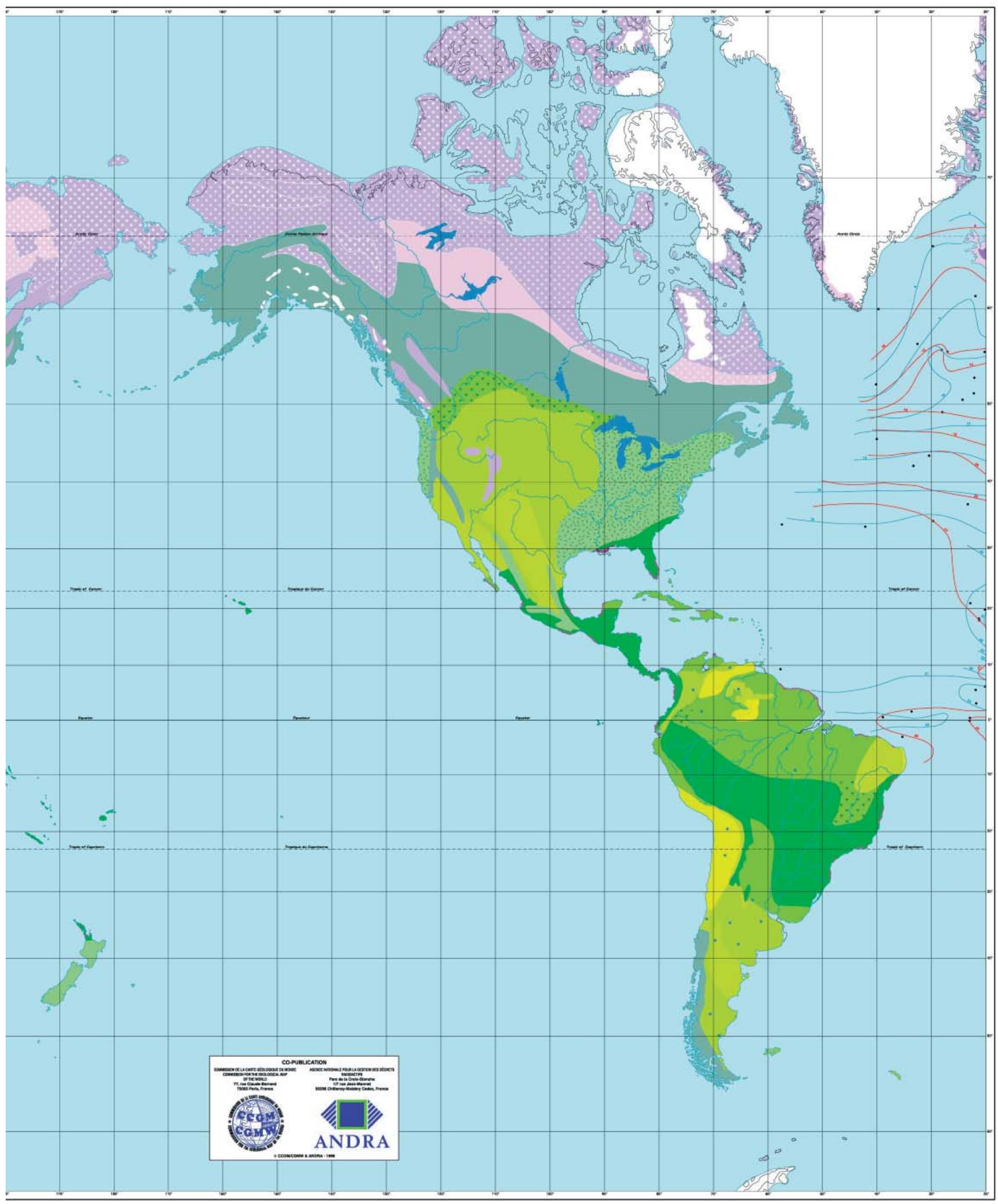

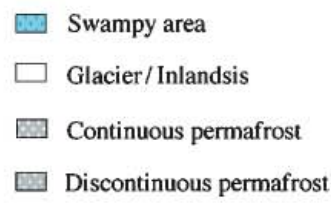

$\square$ Ocean or closed sea

- Core

^ Inlandsis height

Northern summer/Southern winter Sea Surface Temperature

\footnotetext{
Northern winter/Southern summer
Sea Surface Temperature

Present-day shoreline

River
} 
$\pm 2^{\circ} \mathrm{C}$. However, most of these weak anomaly patterns comprise a whole array of largely homogenous SSTs values and appear consistent with major regional oceanographic structures.

During early Holocene, during the northern summer (AugustOctober), the most striking negative SSTs anomalies amount to $3-5^{\circ} \mathrm{C}$ and occur in both the northwest African and south Arabian regions of coastal upwelling. Off Arabia, the reduced SSTs estimates clearly document the well known impact of an intensified Indian summer monsoon, when solar insulation had reached its maximum (Hutson and Prell, 1980; Prell and Kutzbach, 1987). In contrast, the attenuated SSTs off northwest Africa (likewise off southwest Africa during the southern summer) are not so easily understood. They probably reflect a strengthening of the Atlantic eastern boundary currents at this time, since coastal upwelling is most strongly developed in these regions during the winter, along with maximal trade winds.

In the Nordic Seas, the early Holocene SSTs estimates slightly exceed the modern temperature range by more than $1^{\circ} \mathrm{C}$ during both summer and winter, and thus reflect an increased oceanic heat flux to northern high latitudes, during the Holocene climatic optimum. Vice versa, SSTs estimates from the Labrador Current show a uniform cooling by more than $1^{\circ} \mathrm{C}$, which can be traced far across the North Atlantic, a feature suggesting a slightly more dynamic western boundary current.

In conclusion, the data we have presented here show new sea surface temperatures patterns during the Last Glacial Maximum, which approximately follow the classical patterns of CLIMAP. Different from the CLIMAP reconstruction, the LGM Atlantic, as reconstructed by our dataset, is characterized by summer SSTs of about $4^{\circ} \mathrm{C}$ in northern high latitudes of $50-80^{\circ} \mathrm{N}$. These temperatures preclude a perennial sea-ice cover of the Nordic Seas. Near the equator our new SSTs estimates lead to a considerable glacial SSTs drop, reaching up to $5^{\circ}-8^{\circ} \mathrm{C}$, in harmony with various coral and landbased paleotemperature records. During the Holocene Climatic Optimum summer, consistent negative SSTs anomalies reflect an intensified Indian summer monsoon and a strengthening of the Labrador and Atlantic eastern boundary currents. Positive SSTs anomalies in the Nordic Seas suggest a slightly increased oceanic heat flux to northern high latitudes.

\section{Shorelines}

\section{(by Philippe Bouysse and Martin van der Zijp)}

\section{Last Glacial Maximum}

During the LGM, the building of the ice sheets, that required enormous volumes of water extracted from the oceans, led to a global lowering of the mean sea level of $120 \mathrm{~m}$ to $130 \mathrm{~m}$. We have chosen the position of the $125 \mathrm{~m}$ isobath to delineate the shorelines of the LGM (using the ArcInfo software for the Worldwide Digital Terrain Data, CD-ROM release 1.0, April 1995, US Department of Commerce, NOAA, National Geophysical Data Center, Boulder, Colorado). Some specific and bathymetrically sensitive zones of this digitized worldwide database, such as e.g. straits, have been manually improved afterwards.

Large areas of continental shelves were emerged, particularly off eastern Siberia and Alaska, Argentina, eastern and southern Asia. New Guinea was widely connected to Australia; the Persian Gulf had dried up. The Mediterranean Sea, the Red Sea, the Japan Sea were still supplied in oceanic water. In contrast, the Black Sea was completely cut off from the Mediterranean and had become a lake (the Marmara Sea too); during the LGM and up to 15,000 years B.P., its level dropped for about 150 m (C. Kuzucuoglu, pers. com. 1998).

\section{Holocene Climatic Optimum}

As regards the Holocene Optimum and as stressed in the Introduction, the maximum values of the signals for each of the various phenomena taken into account in these maps, are far from being coeval. Thus, the rise of the ocean-level subsequent to the end of the deglaciation, occurred around 6,000 years B.P., i.e. ca 3,000 to 1,000 years later than the climatic Altithermal, and at about the same level as today. Therefore, we have represented for this period the present sea level, with two exceptions:

- for the Canadian Arctic and the Baltic area, we have taken into account the delay in the isostatic readjustment due to the melting of the North American and Scandinavian inlandsis (inland ice) and the eustatic rise (see Permafrost section);

- the deltas of the main rivers (Mississippi, Amazon, Rio de la Plata, Euphrates-Tigris, Yangtze...), had not yet reached their present extension, the Holocene transgression just terminating. This is particularly obvious for the lower Mesopotamia.

We again refer to the peculiar case of the Black Sea (C. Kuzucuoglu, pers. com., 1998), the level of which was controlled by the shallow depth of the Bosphorus threshold $(-30 \mathrm{~m})$ and, to a lesser degree, by that of the Dardanelles $(-60 \mathrm{~m})$ : from 15,000 years B.P. a rise of its water level took place following the deglaciation of northern Europe which provided the Black Sea with fluvial waters. This fresh water flowed into the Mediterranean, the level of which was rising at a slower pace. This situation persisted until ca. 12,000 years B.P. It was until about 7,500 years B.P. that the Mediterranean waters could pour again into the Black Sea.

\section{Ice sheets and valley glaciers}

\section{(by Geoffrey Boulton)}

The two maps show the limits of glaciers at the Last Glacial Maximum (LGM) and at the time of the Holocene Climatic Optimum (HOP). These two periods pose different problems.

For the LGM, it has generally been possible, in areas which have been subject to intensive field mapping, to determine the maximum extent of glaciers during the last glacial period. However, there is strong evidence that the maximum extent was reached in different places at different times, although there are few localities at which the precise date of glacial maxima can be established. We have therefore simply mapped the maximum extent which glaciers are believed to have attained during the time period 22,000 to 14,000 years B.P., which covers the global range within which the maximum is believed to have occurred.

Rapid retreat of glaciers after the LGM led to their disappearance from many areas before the HOP. Because it is intrinsically difficult to determine precise dating of particular stages of glacier retreat, it is often difficult to determine exact locations of glacier margins at the HOP. In many areas where glaciers exist at the present day, Little Ice Age cooling caused many glaciers to readvance, during the 16th to the 19th centuries, to beyond their HOP extent, thereby obliterating the evidence of that extent.

In many areas of mountain glaciation, where glaciers are restricted to narrow mountain valleys or to narrow ridge crests, it is difficult to represent them on a map of this scale. We have therefore only represented glaciers whose minimum width is greater than 20 $\mathrm{km}$. Many expanded ancestors of modern glaciers, such as on Kilimanjaro and Mount Kenya in East Africa are therefore too small to be represented on the maps.

Glaciers in the Holocene and at the LGM comprise:

Ice sheets. These are continental scale ice domes with summit elevations in excess of $2-3 \mathrm{~km}$. There are two modern ice sheets, those of Antarctica and of Greenland. During the LGM, large ice sheets also occurred over North America, Europe and on the Eurasian continental shelves. Over much of their area they flow relatively sluggishly away from summit ice divides, but fast flowing 
streams of ice, which cover only a small area but discharge a large proportion of the ice mass, flow radially towards their margins. The lobate southern margin of the North American ice sheet for instance, reflects the locations at which ice streams reached the ice sheet margin.

Ice caps. These are smaller, regional ice domes, 10s-100s km in diameter, such as those of Iceland and Baffin Island.

Valley glaciers. These occur in mountain areas and where they may cover a large proportion of an upland mass, such as in the European Alps, the Andes and Himalayas.

Small ice masses, such as small summit ice domes and cirque glaciers.

The only ice masses large enough to be shown on the maps are ice sheets, large ice caps and dense networks of valley glaciers

The representation of the sea-ice or ice-pack (resulting from the freezing of the surficial ocean water) was intentionally discarded because we do not know with enough accuracy the pattern, the intensity and the thermal characteristics of the oceanic currents towards the high latitudes, during the epochs considered here.

\section{Last Glacial Maximum}

The southern, terrestrial margins of the North American ice sheet are well known, and its western and eastern marine margins are also relatively well-known from marine geophysical surveys (Dyke and Prest, 1987) which show that the ice sheet extended to or near to the edge of the continental shelf. There remains uncertainty about the extent of the northern flank of the ice sheet. According to Dyke and Prest (1987), the ice sheet did not extend over the Queen Elizabeth Islands, whereas Blake (1970) has suggested that the ice sheet covered the area. We accept the reconstruction of Hamilton and Thorson (1993) of the extent of glaciers in Alaska, and that of Porter and co-workers (1993) for other glaciers south of the ice sheet in North America.

For the LGM in South America, we use the reconstruction of Clapperton (1993). The whole of the land area of Greenland was covered by an ice sheet during the LGM but its extent across the continental shelf has not yet been completely established. We use the reconstruction of Funder and Hansen (1996), which assumes that the LGM ice margin lay at the continental shelf edge. A similar assumption is made in the case of Iceland (Ingolfsson, 1991) and the Shetland Islands (Boulton et al., 1991).

The ice sheet complex shown extending from Scandinavia to the east of the Urals is believed to have consisted of at least three major domes; over Scandinavia, the Barents Sea and the Kara Sea. The southern margin of the Scandinavian ice sheet is well established by mapping, although there remains uncertainty about whether it was confluent with the ice sheet over the British Isles in the northern North Sea area at some time during the LGM (Sejrup et al., 1994). Although there is now a consensus that an LGM Barents Sea ice sheet existed (Landvik et al., 1998), which underwent early rapid deglaciation at about $15,000 \mathrm{BP}$, its northern margins are poorly known. There is a general consensus for a Kara Sea ice sheet (Forman et al., 1995), and although we have used the conclusions of Velichko and coworkers (1984) and Faustova and Velichko (1992) for the eastern margin for this ice sheet, some believe (e.g. Grosswald, 1980) that there was also extensive ice sheet glaciation in Siberia, as far as the eastern part of the Taimyr Peninsula (i.e. the area shaded in light violet on the LGM map). The locations of the southern margins of LGM ice sheets in Russia is also relatively uncertain. This area of northern Russia and the adjacent continental shelf remains the area of greatest uncertainty in the distribution of large ice sheets at the LGM. The extent of the smaller ice masses in Asiatic Russia follows the reconstruction of Velichko and co-workers (1984).

The extent of glaciation in the Tibetan and Himalayan regions is shown following authors summarised by Derbyshire et al (1991). It shows an extensive complex of ice caps and valley glaciers in the mountain zones. We believe that the balance of evidence is against an ice sheet over Tibet and adjoining regions at the LGM, as suggested by Kuhle (1988).

The extent of the LGM ice sheet over the British Isles follows Boulton et al. (1991) and the ice complex in the European Alps follows Denton and Hughes (1981).

The extent of the Antarctic ice sheet at the LGM is derived from the reconstruction by Denton and co-workers (1991). In some areas this lies short of the edge of the continental shelf. However, recent marine geophysical work suggests that the ice sheet in the sector did extend to the shelf edge, and may have done so more widely.

\section{Holocene Climatic Optimum}

For North America, we accept the Dyke and Prest (1987) reconstruction. For South America, we assume that the extent of glaciers was not significantly different from that of the present day, although more work is needed to confirm whether this was so.

Data from west Greenland (van Tatenhove, 1995) indicates the position of the HOP ice margin but there are few other constraints on estimation for the rest of the Greenland ice sheet margin. In Iceland, we assume that glacier margins lay within the modern glacier limits.

In Eurasia, the evidence of glacier extent during the HOP is poor, but glaciation was clearly very restricted. We have assumed that it lay within the extent of modern glaciation.

\section{Permafrost}

\section{(by Brigitte Van Vliet-Lanö̈ and Olga Lisitsyna)}

A distinction has been made between continuous and discontinuous permafrost. Continuous permafrost covers an average $80 \%$ of the landscape, while the discontinuous one covers from $79 \%$ to $10 \%$. Unfrozen spots may remain in both cases, related to water bodies, vegetation, topographical orientation and geothermal gradient (Kudryavtsev, 1978; Washburn, 1979). Continentality, by reducing snow cover, may also favour permafrost extent. On the other hand, permafrost in hypercontinental regions may provide sufficient humidity to develop a forest in arid conditions (Yakoutia, Mongolia, Yukon, etc.)

As concerns the territory of the ex-USSR, the work of compilation was guided by both the wide distribution of present-day permafrost and the availability of accurate information on the recent and paleocryolithozones. Paleo-permafrost mapping work was based on existing contemporary and paleo-permafrost maps at various scales (e.g. Baulin et al., 1981; Velichko, 1984; Ershov, 1988-1989) and, basically, the Geocryological Map of the USSR at 1:2,500,000 scale (Ershov, 1997). Present-day geocryological maps provide reliable information on the distribution of permafrost, its structure, thickness, temperature, ice content, recent and past periglacial processes and phenomena, and therefore, data for paleo-permafrost reconstruction. Relief features indicative of permafrost activity during the two considered climatic extremes have been taken into account, both within the area of today's permafrost distribution (two-layers and degrading permafrost, ice complex sediments, various types of massive ground ice, lake thermokarst, etc.) and outside its limits (relict permafrost, geothermal anomalies, wide distribution of the zone of gas hydrate stability, fossil periglacial phenomena and microtopography etc.). The reconstruction of paleo-permafrost conditions has also taken into account other phenomena, such as frost peat mounds, pattern grounds, kurums, solifluction forms, etc. For the regions without any direct permafrost indicators, the mean annual ground temperature was estimated by using the recent ground temperature from the Geocryological Map (Ershov, 1997). Additional information was provided by palynological, paleo-zoological and other recorded data.

In western Europe, data are based mostly on the utilisation of fossil periglacial features, such as ice and sand wedge casts, thermal cracks, fragipan horizons, systematic occurrence of cryoturbation or 
solifluction, evidence of strong ice segregation in sediments and fossil rock glaciers. Actually, this is an intermediate position between two opposite assumptions (Vandenberghe, 1993; Vandenberghe and Pissart, 1993; vs Gangloff et al., 1994), but closer to that of Kaiser (1969) and Maarleveld (1976). Loading and slumping related to neotectonism have been rejected from the "periglacial record", since they were often the cause of confusion.

In the USA, fossil data come mostly from Pewe, 1983 and soil maps (various fragipan horizons) that were matched with present day frost penetration at $1 \mathrm{~m}$ depth (Washburn, 1979).

In Japan, information is scarce and few new facts are available since Washburn, 1979. For the Middle East, an altitudinal / latitudinal gradient similar to Europe was applied.

\section{Last Glacial Maximum}

In North America, permafrost extended north of the Ice Sheet and into the Porcupine corridor, between the Laurentidian dome and the northern Rockies (Porter, 1988). South of the ice sheet, continuous permafrost extended to Wyoming and Idaho (Mears, 1981; Pewe, 1983) and probably spread beyond the extent of ice wedge casts, a feature commonly used to define continuous permafrost related to catabatic winds. The proposed southern boundary is about $300 \mathrm{~km}$ south of that of Pewe because of 1) the frequency of fragipan displaying polygonal bleached patterns, somewhat marked from a pedological point of view by a modification of the fragipan during the Holocene pedogenesis (slight silica cementation), 2) the aridity of the region at the LGM, and 3) the inclination of the latitudinal gradient compared to Eurasia. Moreover, the Mississippi valley was the outlet of the Laurentidian Ice Sheet and, in terms of loess repartition (Porter, 1988), also a true wind corridor.

In Eurasia, the LGM was characterised by a maximal extent of permafrost spreading over most of Europe and the whole of Siberia. It was under the control of latitude and of altitudinal gradients, due to the hypercontinental regime of this area. The general southern limit of permafrost reached $40^{\circ} \mathrm{N}$, and even farther, towards lower latitudes, in Tibet and in the Himalayan Ranges.

One of the main features of the LGM was the accumulation of the ice complex with syngenetic ice wedges up to $10-60 \mathrm{~m}$ thick. The ice complex itself is evidence of harsh geocryologic conditions (low temperature of ground, continuous distribution of permafrost with subaerial conditions contributing to its formation) and of the absence of glaciation or marine transgression in the area. Fragments of ice complex in the mountain depressions of south-eastern Siberia are indicative of the extensive distribution of continuous permafrost in these areas, during the LGM.

A wide distribution of ice wedge casts and soil wedges in the Late Valdai (Sartan) deposits, as well as a generalised polygonal topography in southern ex-USSR (except for the southwestern part) provides evidence (Spasskaya et al., 1993; Velichko, 1984) that permafrost extended much farther south than the boundaries of exUSSR. This wide extent is responsible for the relict permafrost of North-Eastern Europe and West Siberia, which is indicative of the continuous permafrost distribution in these regions during the LGM (Romanovskii,1993). Deep seasonal freezing of ground and alpine (high-mountains) permafrost developed in the south-west (south of $48^{\circ} / 49^{\circ} \mathrm{N}$ ): Crimea, Caucasus, Kopet Dagh mountains. The average ground temperature during the LGM was about $8^{\circ} \mathrm{C}$ to $10^{\circ} \mathrm{C}$ lower than today.

In Europe, at low altitude, permafrost extended in a discontinuous form over the Aquitaine (France, ca. $44^{\circ} \mathrm{N}$ ), at about the same latitude as in the USA, as a consequence of the disappearance of the Gulf stream $\left(\mathrm{a} 10^{\circ} \mathrm{C}\right.$ decline of the sea surface temperature) and a strong aridity (no snow cover protection), especially in the south of the Pyrenean belt. However, during the LMG, permafrost never reached the Po plain (Cremachi \& Van Vliet-Lanoë, 1991). The ice wedge polygon boundary extended from Devon to the north of the Azov Sea, about $300 \mathrm{~km}$ to the north of the southern boundary of permafrost, traced by the extent of periglacial type of fragipan soils. In mid-altitude regions of the Massif Central, Spain, Yugoslavia (s.1.), Greece and Anatolia, mountain permafrost developed, as it has been particularly corroborated by fossil rock glaciers or large pattern grounds. The west coast of Iberia was devoid of permafrost, even in Galicia. In the eastern Pyrenean belt, it reached $800 \mathrm{~m}$. In North Africa and in southern Spain mountain permafrost reached 1,200 m in the Betic cordillera and 2,000 $\mathrm{m}$ in the Atlas.

In Iran and Pakistan, it seems that mountain permafrost have been mostly linked to altitude and to aridity, but reliable data is lacking (confusions with co-seismic and desiccation patterns). The Tibetan plateau was covered with a continuous permafrost that did not reach the Nepal depression. In China (Inner Mongolia and Northeast China), as well as in Japan (Hokkaido), discontinuous permafrost extended at low altitude from about $43^{\circ} \mathrm{N}$, following the same latitudinal extension as in Siberia.

In the southern hemisphere, permafrost extended at low altitude in South America, as far north as $40^{\circ} \mathrm{S}$, particularly at mid-altitude in the Central Valley of Chile and in Patagonia, as a result of aridity. It remained absent in the Falklands/Malvinas Islands. It was also widespread in the southern island of New Zealand. Moreover, mountain permafrost extended further to the north with a spot in south-east Australia and above $500 \mathrm{~m}$ in Tasmania. It seems possible that, in islands located south of $55^{\circ} \mathrm{S}$, such as Bouvet, Kerguelen, South Orkney, South Georgia (present day permafrost) and MacDonald, mountain permafrost developed at least on the unglaciated summits. On the contrary, it never existed in southern Africa, except for a small spot of mountain permafrost in the Drakensberg.

\section{Holocene Climatic Optimum}

In North America, the situation is rather clear concerning the Hypsithermal Optimum. Warming was very abrupt at the onset of the Holocene, leading to the early development of permafrost thaw lakes in the Mackenzie delta region (Murton \& French, 1993; Burn, 1997). Two recent syntheses have been published by Zoltai and by Richard in 1995. The maximal extent of the tree line in Nunavik (Quebec) corresponds probably to the southern boundary of permafrost at that time. Additional information has been gathered during fieldwork in Ungava and Northern Quebec, in collaboration with the Centre d'Études Nordiques, Laval University at Quebec. It is representative of the opinion of one of us (B.V.V.L.) and is concordant with the data proposed by P. Richard (1995) and by S. Payette and C. Morneau (1993). In Western Canada, summer temperatures were about $5^{\circ} \mathrm{C}$ warmer than today (Zoltai, 1995). The most southern extent of permafrost was found in north-eastern Canada (Richard, 1995) which is related to the cold Greenland sea current, residual small ice caps, low precipitation (sand wedge growth) and to vegetation anomalies. It is also responsible for an early presence of permafrost before the main pedogenesis. On the western cordilleras, it is probably preserved in altitude but data is missing.

In Eurasia, the southern boundary of permafrost was reconstructed according to present-day distribution of Late Pleistocene and more ancient frozen syngenetic deposits: taliks, hummocky peatlands, etc. The northward advance of a limit of thermophilous vegetation was also taken into account. The Holocene Optimum stage in this region corresponds to the mildest permafrost conditions: the most northward migration of the southern boundary of permafrost, the highest ground temperature, the thickest active layer, the formation of thermokarst lakes and depressions, hilly-sinking topography, etc. As was the case in Northern America, there was a rapid thawing of perennially frozen grounds. Permafrost retreated to the North and the thickest permafrost thawed partially, forming the relict permafrost observed at depth today in West Siberia and in the northeast of the Russian plain. Alpine permafrost remained in the Stanovoi Range, the Aldan and the Sayan Mountains and even in more southern mountains. The occurrence of syngenetic ice-rich sediments and massive ice of the Late Pleistocene and more ancient age is both indicative of the continuous permafrost distribution during the Glacial Maximum and of its preservation in the Holocene Optimum. At present, a sharp change in permafrost thickness varying from $100-150 \mathrm{~m}$ to $300 \mathrm{~m}$ and more in the Siberian platform is 
providing information about the southern boundary of permafrost distribution during the Holocene Optimum. As a matter of fact, permafrost over $300 \mathrm{~m}$ thick could not form during the Interglacial.

The Holocene thawing which induced the destruction of high ice content in the syngenetic deposits led to the formation of the "inverted" (thermokarst) relief. This fact accounted for the southern limit of continuous permafrost during the Hypsithermal, coinciding with the southern limit of massive ice spreading, and also for the high ice content and "inverted" relief. Hummocky peatlands, nowadays widespread within the southern permafrost zone of North-Eastern Europe and Western Siberia, denoted a degradation of permafrost during the Holocene Optimum and the existence of peat bogs or lake depressions (Baulin et al., 1981). Temperatures were about $1^{\circ} \mathrm{C}$ to $3^{\circ} \mathrm{C}$ higher than today (Velichko, 1984).

In Europe, all prospecting works (cf. King and Seppälä, 1987) have shown that permafrost disappeared in Scandinavia and that even precipitation was rather low at that time (local eolian activity up to 7000 B.P.). Moreover, part of the defrosted lithosphere had not been re-equilibrated from a glacio-isostatic point of view and lay below sea level. Permafrost was probably absent of Iceland. In Svalbard, temperatures were higher of at least about $2^{\circ} \mathrm{C}$ in summer, with possibly some discontinuous permafrost on the Western coast (Landvik et al.,1988). Permafrost was probably absent in the Urals mountains. In the Alps, it was mainly restricted in altitude, above $3000 \mathrm{~m}$, in the vicinity of residual glaciers, but this is an approximation based on glaciers positions during the Middle Age Optimum (Leroy-Ladurie, 1983).

In Tibet, permafrost was absent as a consequence of a high geothermal gradient (Shi, 1988), except for the northern part of the plateau, where it was discontinuous, despite the altitude.

In southern Asia, it was also probably restricted to the higher mountain ranges, but no sound data is available.

For the southern hemisphere, the information is given regionally. Continuous permafrost existed on the Antarctic Peninsula.

Let us recall here that, in the northern hemisphere, the high latitudes lithosphere, released from the burden of the ice caps, had not reached an isostatic equilibrium, as well as in North America, Scandinavia and several present day coastal zones that were still submerged (Hudson Bay, Canadian Arctic archipelago, Baltic Sea).

In conclusion, during the LGM, permafrost extended southwards to latitudes of $40^{\circ}$ to $44^{\circ} \mathrm{N}$ in the Northern hemisphere, with local accommodations induced by relief and by the more or less massive continental shape. It was mostly absent in the Southern Hemisphere, except for Patagonia and the South Island of New Zealand. During the Hypsithermal, it was restricted to approximately the present boundary of continuous permafrost in the Northern Hemisphere. The present extent of continuous and discontinuous permafrost, which started at about 4,500 yrs. B.P., represents approximately $30 \%$ of the surface comprised between the full glacial conditions and those of the Holocene Altithermal.

\section{Eolian formations and arid zones}

\section{(by Martin Iriondo, Tim Partridge and Nicole Petit- Maire)}

\section{Last Glacial Maximum}

As a general rule, the LGM led to a decrease of rainfall in wide areas near the tropics and to an extension of the deserts. The subsequent reduction of the vegetation cover favoured a strong eolian corrosion of the rocks that resulted into sand or loess outspread over vast areas of transfer, or deposited as dune bodies.

Loess is widely distributed in periglacial areas, and dunes in semi-arid or arid regions. Only active sedimentary structures have been plotted on the map, mainly large ergs, although no indication of their orientation is provided because, on one hand, the relevant infor- mation for the entire world is not available and on the other hand, we had to limit, as much as possible, the cartographic overprints.

In general, the extension of the deserts was wider than nowadays: the Sahara, the Arabian Peninsula, China, northwest India (Thar desert), Namib, Kalahari, Australia. Several hundred of kilometers of large longitudinal dune systems (ergs) were built over the Sahara and the present day Sahel, as well as on the Arabian Peninsula. In China, the well-marked continentality, enhanced by the withdrawal of the sea to the east, was a factor of increased aridity that induced the sedimentation of thick layers of loess in the centre of the country. In the north of Botswana, south of Angola and in Zambia, dune fields were active during the LGM, thereby implying volumes of rainfall less than 100-150 mm. In South America, the eolian drift of silt and fine sand was widespread (Iriondo, 1997). Winds derived from the Southern Pacific anticyclone crossed over the Andes generating the Pampean eolian system (Iriondo and Krohling, 1996). In north-eastern Brazil, southeast trade winds activated successive eolian formations (Barreto et al., 1997). Dune fields of probable glacial age were widespread in the Llanos of the Orinoco (Roa, 1979; Khobzy, 1981) and in northern Brazil (Santos, 1993).

The most spectacular extension of arid zones was observed in the Sahara: during the LGM the desert advanced 300 to $400 \mathrm{~km}$ southwards with respect to the present day Sahara-Sahel boundary. Ergs were continuous on the desert and the present day Sahel, substantiating a southward shift of the $100-150 \mathrm{~mm}$ isohyet of some $4^{\circ}$ in latitude $\left(17^{\circ} \mathrm{N}-13^{\circ} \mathrm{N}\right)$ in relation to the present situation. The Nile delta was also subject to a harsh phase of aridity that brought on the edification of the wide dune fields of the Rub al Khali and the Nafud, in Arabia.

On the other hand, in Central Asia, the situation was somewhat different due to the effect of the seasonal melting waters from the ice cap fronts and to the fact that, in general, this region was wetter then than during subsequent times.

\section{Holocene Climatic Optimum}

There are no significant records of active eolian deposition during the Holocene Altithermal. In the Sahara, a hydrological optimum occurred between 9500 and 6500 years B.P. (Petit-Maire et al., 1994; Petit-Maire and Bryson, 1998) that brought on wide fresh water surfaces, steppe vegetation and, south of the tropic, a fauna of big mammals. The rainfall was several tens times higher than the present day values and a graminea steppe existed up to ca. $22^{\circ}-23^{\circ}$ $\mathrm{N}$, i.e, some $1,000 \mathrm{~km}$ northward with respect to the LGM situation (and some $500 \mathrm{~km}$ more northward in relation to nowadays). In the Arabian Peninsula, the wet phase was less pronounced than in Sudan (Sanlaville, 1994; Pachur and Kröplin, 1987), whereas in the southwestern corner of the peninsula, in Yemen, the strengthening of the monsoon produced important rainfalls over the mountain ranges and highlands (Lézine, 1998).

In South America, a weak mobilisation of sand and silt by the wind was observed in relation to the Hypsithermal; its was restricted to the Orinoco and northeastern Brazil (Roa, 1979; Barreto et al., 1997).

On the contrary, in Central Asia and particularly around the Aral Sea, as well as in the coastal deserts of northern Chile (e.g. Atacama) and southern Peru, the aridity seemed to be stronger than during the LGM.

\section{Surface fresh water}

\section{(by Philippe Bouysse, Martin Iriondo, Peter Kershaw, Tim Partridge, Nicole Petit-Maire, Brigitte Van Vliet- Lanö̈ and Zhuo Zheng)}

The presence or the absence of surface fresh water provides climatologists with evidence of the occurrence of a positive or negative balance of the ratio Precipitation/Evaporation in regions (namely 
endoreic depressions) wherever the nature of the substratum and the geographical conditions allow it. Hence, known lacustrine areas have been plotted on the maps, even if the data for these areas differ in quality. The paleolakes are represented by conventional dots when (for most of the cases) their size is unknown or too small relatively to the scale of the map. No distinction has been made between permanent and seasonal lakes because accurate data were missing most of the time.

\section{Last Glacial Maximum}

As a result of the increased global aridity, lakes and swampy areas were less important. However, this scheme is not applicable when approaching the front of the northern hemisphere ice-caps. Thus, in Central Asia, the extent of the Caspian and Aral Seas actually lakes - was greater than during the Altithermal and even than nowadays because of the melting waters supplied by the icecaps fronts. The course of some western Siberian rivers was reversed. The west of the USA would have experienced a similar situation. It would seem that several episodes of overflow of the Caspian waters into the Black Sea took place (C. Kuzucuoglu, pers. com., 1998). It is interesting to note the wide lake that formed in the middle of the emerged continental shelf linking Australia to New Guinea (Gulf of Carpentaria).

In Australia, lakes were ephemeral. In South America, as a general rule, the level of lakes was low during the LGM (Wirrmann et al., 1988; Siffedine, 1991; Argollo, 1997; Carignano, 1997), with the exception of the Chilean lakes and of two cases in western Argentina (Gonzales, 1981; Stine \& Stine, 1990).

In China, the level of lakes was low, as in southern Africa. From the north of Africa to the Arabian Peninsula and Rajasthan and the present day arid area extending from the Atlantic to China was deprived from surface water; the water-tables were lower than the bottom of the depressions and the entire present day network of wadies was inactive. In the Sahara, desert conditions prevailed some 300 to $400 \mathrm{~km}$ further south than today.

\section{Holocene Climatic Optimum}

Significantly wetter global conditions prevailed, with frequent occurrences of lacustrine or swampy environments, mainly in the tropical regions and in vast areas located at the margins of transition zones. They are indicative of a hydrological balance differing completely from that of the LGM; in the Sahara, the Arabian Peninsula, Rajasthan, Natal, China and Australia, lakes formed in the depressions and in the troughs of the dunes during the glacial. In Canada, the Great Lakes appeared at the periphery of the former inlandsis. In contrast, Central Asia, deprived from proglacial input, presented drier conditions and the surface of the Aral and Caspian Seas decreased considerably. In South America, the situation was more complex and tended towards an inversion with respect to the LGM.

\section{Vegetation}

\section{Definition of the vegetation zones on the maps}

\section{(by Jacques-Louis de Beaulieu)}

\section{Arctic or alpine tundra*}

Low graminoid vegetation of high latitudes and altitudes above the treeline (draft bushes, grasses, sedges, mosses and lichens) with a short growing summer season. This vegetation type is physiologically and physionomically homogeneous. The mean temperature of the warmest month is below $10^{\circ} \mathrm{C}$; the temperature is above frost conditions only 3 months a year and annual rainfall is generally

*According to O. Lisitsyna, shrub tundra was to be found locally around the Okhotsk Sea during the LGM. below $200 \mathrm{~mm}$. Nevertheless, climate is wet, due to the very low evapotranspiration.

\section{Tundra-steppe}

This vegetation type, which is confined to limited areas in Siberia and to the high latitudes of North America, expanded widely during the LGM. It corresponds to patches of tundra and cold steppes as determined by the water content of the soils.

\section{Taiga}

Open vegetation with bushes, low coniferous and Betula in Eurasia

Our Taiga corresponds to the Northern Taiga of some Scandinavian authors. The mean annual temperature of the warmest month ranges between $10^{\circ} \mathrm{C}$ and $15^{\circ} \mathrm{C}$, but the mean winter minima can fall below $-30^{\circ} \mathrm{C}$. The annual rainfall is generally below $500 \mathrm{~mm}$.

\section{Boreal forest (Southern Taiga)}

A forest with almost exclusively coniferous trees, with discrete occurrence of some deciduous trees, corresponding to the Southern Taiga of Scandinavian authors. The coniferous forests of the subalpine stage at middle latitudes are included in this definition.

\section{Mixed temperate forest}

This type includes a great range of forests, linking deciduous trees and coniferous growing at middle latitudes and altitudes (premontane and montane stages). It broadly corresponds to the "cool mixed" and "cold mixed" biomes of the Prentice classification.

\section{Deciduous temperate forest}

Deciduous forests under temperate climate. The seasonal climatic variations are mostly determined by temperatures changes and the rainfall distribution is favourable to the tree growth. The mean temperatures of the coldest month range between $-5^{\circ} \mathrm{C}$ and $+10^{\circ} \mathrm{C}$; the mean annual precipitation is above $450 \mathrm{~mm}$.

\section{Xerophytic or Mediterranean woodland}

This unit groups vegetation types determined by seasonal drought, associating some deciduous trees (the less arid facies), evergreen trees or low trees and bushes and drought-tolerant coniferous (chapparal, garrigues, maquis, mattorals). The average winter temperatures are generally around $10^{\circ} \mathrm{C}-15^{\circ} \mathrm{C}$, with some frosty days. The annual precipitation ranges between $275 \mathrm{~mm}$ and $900 \mathrm{~mm}$, at least $65 \%$ falling in winter.

\section{Steppe}

This group includes several types of dry vegetation, characterised by low grasses, more or less open but sufficiently continuous (the North American prairie is included in this group). This vegetation type is determined by low precipitation and/or high evaporation, but can suffer high thermal amplitudes. It is therefore observed in the warm domain at the edge of tropical deserts and in the temperate domain in the continental areas. During the LGM, the steppes expanded largely on the areas presently covered by temperate forests and xerophytic woodlands, due to the increased drought.

\section{Savanna}

Vegetation types with tall grasses (Gramineae) with some scattered tree species linked, as the steppes, to a dry climate, although on the margins of the sub-equatorial domain (transition between wooded savannas and tropical deserts).

\section{Wooded steppe / Wooded savanna}

Due to graphic constraints, these two items have been merged. Wooded savanna represents the transition facies between the savanna and the tropical forest, same as the wooded steppe which is 
the transition facies between the continental or Mediterranean steppe and the xerophytic woodland. It seems that, during the LGM, the better watered areas of the regions nowadays occupied by Mediterranean forests or xerophytic woodlands were occupied by steppes.

\section{Tropical/equatorial forest}

This subdivision includes dense forests of different nature; the equatorial rainforest with a precipitation level of more than $1500 \mathrm{~mm}$ per year and rains throughout year, and the seasonal semi-deciduous tropical forest with a combination of deciduous and evergreen trees resulting from a monsoon regime with dry winters. The average annual temperatures are always above $18^{\circ} \mathrm{C}$ and the minimal monthly rainfall is beyond $60 \mathrm{~mm}$. At the present state of paleoenvironmental knowledge, it is preferable to maintain both biomes under the same item.

\section{Arid area}

This term is applied both to deserts with an annual rainfall under $150 \mathrm{~mm}$ per year and strong evapotranspiration, and to semidesert areas in which marked variations of the average annual precipitations are charasteristic.

\section{Mangrove}

This coastal and swampy vegetation covers large areas along the tropical and subtropical coastlines; it is characterised by trees having adapted to root anoxia.

(Mangroves have been mapped only for the Holocene; their extension was probably about the same as nowadays. On the other side, although data for the Last Glacial Maximum were not available, it could be assumed that the absence of significant run-off during this period reduced considerably their extension).

\section{South America}

\section{(by Martin Iriondo)}

According to the available information, climatic belts migrated between 5 and 10 degrees to the north during the LGM, with a general decrease of temperature. During the Hypsithermal, climatic belts shifted southwards, bringing about a dry climate in the north of the continent and higher humidity in the south (Iriondo, 1995; in press). In South America, as well as in the rest of the continents, vegetation formed a patchy mosaic with rainforest around the equator and savannas in the tropics.

At the Last Glacial Maximum the humid belt migrated to the north by about 8-10 degrees (Helms and van der Hammen, 1994), with a dominance of savannas in Central Amazonia (Siffedine, 1991) and semiarid conditions to the south (Lichte, 1991; Behling, 1997). The Patagonian climate shifted to the north-east (Iriondo and García, 1993).

During the Hypsithermal, a dry-climate vegetation occupied the north of the continent (Rinaldi et al., 1990), with savanna in the equatorial belt and humid forest in the southern tropics (Ledru et al., 1997).

\section{Australasian and Southeast Asian region}

\section{(by Peter Kershaw)}

A guide to vegetation reconstruction was provided by the vegetation classification of Specht (1970) mapped for Australia by Carnahan (1976). Specht vegetation types are based on the height and projective foliage cover of the dominant life form, and recent vegetation modeling (Haxeltine et al., 1996) demonstrates good correspondence with climate variations. Inferred vegetation distributions for the LGM and Holocene 'Optimum' are based predominantly on results from palynological records with mapped summaries provided in Markgraf and co-workers (1992) for Australia, New Guinea and New Zealand. Marine palynological records from the China Sea ( $\mathrm{Li}$
$\mathrm{Xu}$, in preparation; Sun Xiangjun, in preparation) from southern Indonesia (van der Kaars, 1991) and the Banda Sea (van der Kaars et al., in review) together with the terrestrial records of van der Kaars and Dam (1995) and Stuijts and co-workers (1988) for Java, Kealhofer and Penny (in press) for Thailand, and Winkler and Wang (1993) for southern China, provided most of the palynological data for reconstructions of terrestrial vegetation in the Southeast Asian region. For the Holocene, the extent of mangroves has been inferred from palynological records (Grindrod, 1988; Moss and Kershaw, in review).

The major problem has concerned vegetation mapping. One aspect of this is the patchiness of palynological sites with greatest concentrations in those areas traditionally selected for such studies i.e. the humid temperate areas of southeastern Australia and their highland counterparts in the tropics, particularly New Guinea. There are few sites from the arid and semi-arid parts of Australia or from the lowland areas of Southeast Asia. Fortunately studies during the course of this Climex project have shed some light on the history of this latter area. Reconstruction has been aided by an apparent similarity in patterns of precipitation as well as temperature change through much of the region with a dry glacial and wet mid-Holocene although uncertainty in precipitation changes is evident in some areas, particularly the south-west of Australia and southern China.

Another limitation to mapping has been the nature of the Australian flora and vegetation, which has a number of distinct characteristics. The isolation of the continent, together with its aridity, climate variability and vulnerability to fire, have led to the evolution of a unique vegetation landscape, dominated by a few taxons such as the eucalyptus, casuarinas and acacias, which inhibit easy separation of community types in the fossil record and their easy classification in a global biome system. It is unfortunate, for example, that the mixed temperate forest category incorporates what is essentially a temperate extension of tropical rainforest in Australia and New Zealand, and eucalyptus dominated, sclerophyll forests in southern Australia which are floristically, structurally and ecologically very different. Similarly, there is little in common between the dry forests of mainland southeastern Asia and the savannas and woodlands of Australia, except that they develop under relatively dry and generally seasonal conditions.

\section{New Zealand}

\section{(by Jane Soons)}

The most comprehensive account of the vegetation cover in New Zealand at both periods covered by the maps is that of McGlone (1988). This brief summary is based on McGlone's essay, which should be consulted for a full overview of changes.

Because of the maritime position, latitudinal extent, and varied relief of the New Zealand islands, the vegetation types shown on the two maps give only a generalized picture of contemporary environments. At the peak of the last glacial the climate was, as at present, under the influence of westerly air flows. This gives strong precipitation gradients across both islands, and a snowline rising from west to east (Porter, 1975; Soons, 1979). Extensive glaciation was confined to the Southern Alps, with glaciers reaching the coast only on the southern half of the west coast of the South Island. Elsewhere in the South Island, some small glaciers were present in the northwest, on the Kaikoura Ranges, and on the highest mountain of Stewart Island. The higher volcanic mountains of the North Island also carried small glaciers.

Only the block mountains of relatively continental Central Otago, east of the Southern Alps, show evidence of severe climate conditions leading to formation of seasonal and discontinuous permafrost (Soons and Price, 1990). Over most of the lowlands a mix of grassland and scrub was dominant, but is likely that forest remnants survived wherever local topography and climate provided relatively sheltered conditions.

In both islands, wind rather than low temperatures is likely to have been the major factor in restricting tree growth (McGlone, 
1988). The forest remnants were nuclei for rapid replacement of the grassland/scrub associations, at the beginning of the Holocene.

Reafforestation in the South Island was substantially complete by about 10,000 years B.P. At 6,000 years B.P. both islands were forested, apart from small localized areas such as recent volcanic deposits, coastal dunefields and mountain areas above treeline. There is some evidence that, in the early mid-Holocene, forest composition was a little different from that of 6000 years B.P., reflecting a change from a slightly warmer and moister climate. At all times, however, the forests were evergreen, with Podocarp/broadleaf species dominant. Kauri (Agathis australis) was a distinctive component in the north of the North Island while, elsewhere, rimu (Dacrydium cupressinum) was important, together with a range of other Podocarps. Mixed Podocarp/broadleaf forest covered large areas of the South Island, but Nothofagus species were also present, becoming dominant in uplands and areas of poor soils. Above the treeline, a mix of shrub and tussock grassland replaced forest.

\section{Africa, South of the Equator}

\section{(abridged from Tim Partridge et al., 1998)}

The reconstructions of the paleoenvironments are based on more than 100 records for Africa south of the equator. During the LGM, dating control, based largely on radiocarbon ages, is, in any case, insufficiently precise to permit a high level of accuracy. During the Holocene Altithermal, on the other hand, trends are better constrained in time, with "optimum" conditions evidently occurring earlier in the north than in the south (Scott, 1993).

The majority of the interpretations are from palynological evidence, but proxy records have also been reconstructed from micromammals, charcoal, paleosols, glacial and periglacial evidence, lake levels, environmental isotopes, diatoms, geomorphological evidence for changing river regimes, dune distributions and sedimentary granulometry.

\section{Last Glacial Maximum}

Temperature depression during the LGM is well documented in South Africa and Namibia from a number of long terrestrial records (Heaton et al., 1986; Talma and Vogel, 1992; Stute and Talma, in press). All indicate a maximum glacial cooling of about $5^{\circ} \mathrm{C}$, supporting the conclusion that, at least in the area between $24^{\circ}$ and $33^{\circ}$ $\mathrm{S}$, temperature depression was constant in relation to present values. Nearer to the equator, the proxy evidence is less reliable, but reconstructions of vegetation cover in Zambia, the Democratic Republic of Congo (Kinshasa) and the lake region of East Africa provide some guides (Livingstone, 1971; Stager, 1988; Bonnefille et al., 1990; Runge and Runge, 1995). Glacial advances on the equatorial mountains of East Africa suggest that, at higher altitudes, the temperature decline may have been of the order of $7-10^{\circ} \mathrm{C}$ (Rosqvist, 1990).

Reconstructions of the probable distribution of major biomes during the LGM reflect the combined influence of temperature depression and desiccation. South of about $13^{\circ} \mathrm{S}$, desert evidently occupied almost the entire western half of the subcontinent. Most of the remaining area was covered by xerophytic woodland, shrubland and grassland, with rainforest restricted to a small area in the western part of the equatorial belt (Maley, 1993).

\section{Holocene Climatic Optimum}

Evidence from various sources (aquifers, speleothems, glacial recession on the East African mountains) indicates that maximum Holocene temperatures occurred between 8,000 and 6,000 years B.P. (Heaton et al., 1986; Talma and Vogel, 1992; Mahaney, 1990) with a warming of $1-2^{\circ} \mathrm{C}$ with respect to the present day situation, and a temperature peak for that area placed between 7,000 and 6,500 years B.P. (Scott, 1993).

While the temperature increase was evidently modest and of similar amplitude over wide areas, changes in precipitation patterns seem to have been more complex. The Kalahari region, in the southwestern interior of the subcontinent, appears to have enjoyed higher rainfall, on the basis of palynological evidence (Scott, 1993). In contrast, evidence for a reduction in the transporting power of streams crossing the Namib Desert from the western escarpment, indicates a decrease in what little rain this area received after 8,000 years B.P. (Vogel, 1987). A similar reduction apparently occurred in the southern Karoo, probably as a result of the reduced influence of the westerlies as temperatures increased and the circumpolar vortex contracted. On the other hand, modest increases are inferred from the coastal area of Kwazulu-Natal. A larger increase, indicated both by lake levels and palynological evidence from the East African Rift area, can be ascribed to an increased influence of easterlies carrying moisture from tropical latitudes of the west Indian Ocean.

Of particular interest is the indication, from various data sources, that much of the Transvaal and southern Zimbabwe experienced reduced rainfall during the Holocene Altithermal. Viewed in conjunction with wetter conditions in the Kalahari, this response is consistent with a westward displacement of the quasi-stationary summer lower tropospheric standing wave over the latter area. With such displacement, eastern areas tend to become drier as the locus of increased rainfall shifts westwards.

Reconstructed vegetation distributions over southern Africa during the Holocene altithermal are much the same as those of today.

\section{China}

\section{(by Zhuo Zheng, Zhengtang Guo, and Nicole Petit-Maire)}

\section{Last Glacial Maximum}

At the LGM, the mean annual temperatures were $7^{\circ}$ to $10^{\circ} \mathrm{C}$ and $4^{\circ} \mathrm{C}$ to $6^{\circ} \mathrm{C}$ lower than today in the north and the south of China, respectively. A large number of palynological data indicate that both desert and steppe vegetation invaded the eastern and north-eastern part of China (Kong et al., 1994) to the detriment of temperate forests that migrated southwards; conifers replaced deciduous species and tropical forest disappeared in China. In Tibet, a desertsteppe vegetation covered the greatest part of the plateau. Only forest formations with a treeline located about 1,200 $\mathrm{m}$ lower than today were preserved in the extreme south and east of the plateau.

\section{Holocene Climatic Optimum}

At the Holocene Altithermal, a boreal conifer forest extended north of the 50th parallel, i.e. about $200 \mathrm{~km}$ further north than nowadays. Temperate mixed and deciduous forests covered a large part of northern and north-eastern China, i.e. some $500 \mathrm{~km}$ further north than today.

The present day steppes of Inner Mongolia were covered with a forest or a wooded steppe. The subtropical, monsoon, evergreen broad-leaved forest extended up to around $35^{\circ}-37^{\circ} \mathrm{N}$ in the domain of the Yangtze River. The mangrove was very developed in the coastal areas of Fujian and Guangdong provinces. From 8,000 years B.P. on, sub-alpine conifers were found in western China. In the central Tibetan plateau, an alpine steppe developed all over between 9,600 and 6,000 years B.P. Western Tibet was occupied by a steppe, inferring higher precipitation in comparison with the arid climate at the LGM (cf. Zheng et al., 1998).

\section{Conclusions}

\section{(by Nicole Petit-Maire, Philippe Bouysse, and Jacques Brulhet)}

When the two series of maps presented in this work are placed side by side, the visual contrast is astounding. In the span of only 10,000 years - a short period of time at the geological scale-and with a difference in the average global temperature of about $6^{\circ} \mathrm{C}$, our 
planet's environment has undergone important changes, between the last glacial extreme and the climatic optimum that followed, such as: - the disappearance in less than 100 centuries of the vast inlandsis of Canada and Eurasia, the height of which could reach up to 4 $\mathrm{km}$ and that covered about 25 million $\mathrm{km}^{2}$,

- as a consequence of this massive ice-melting, some 20 million $\mathrm{km}^{2}$ of continental platform are submerged again by the sea; Homo sapiens sapiens can no longer go by foot from Asia to America, nor from New Guinea to Australia, or France to England,

- the important fluctuation of the surfaces covered by the arid zones and the forests, be it rainforest, temperate or boreal forests: the rainforest regains wide surfaces, the taiga and the boreal forest replace a large part of the tundra or reoccupy lands freed from the ice grip.

Obviously, this natural warming of the past cannot be taken as an exact analogue for the warming induced by the atmospheric pollution forecast by models, all the more since they result from different causes. However, some effects on the environment would most probably be of a similar nature, for example the increase in the activity and range of the monsoon. Anyhow, we have here a picture of the natural variability of major environmental factors that can help us detect unnatural changes occurring under thermal conditions that do not exceed $-5^{\circ} \mathrm{C}$ to $+2^{\circ} \mathrm{C}$ relative to the global average temperature in present-day conditions. Moreover, these maps allow the identification of the most climatically stable areas of our planet.

These maps are also a useful tool for projects concerning a distant future. Ascertaining the consequences of human activities, in the future, becomes, indeed, the main concern of a society increasingly mindful of the quality of its environment and of the legacy that it will pass on to future generations. This concern of prospective is particularly relevant in the studies carried out for the management of nuclear waste with a life span of tens and hundreds thousands of years. It implies to consider thoroughly long periods of time that are necessarily related to the duration of the natural evolution, and to draw the conclusions essential for the conception of nuclear waste storage.

The implementation of these geoprospective scopes, developing according to the needs of the project, considers the analysis of the past in order to foresee the future History. To this effect, understanding the past geological evolution of phenomena and its mechanisms, with their own dynamics and couplings, appears to be a key tool for depicting the future. The analysis of Earth's archives is the way to go backwards in time for the quantification of these natural phenomena: velocity, duration, range, recurrence and thresholds that determine the occurrence of extreme situations. These quantifications, in which time is an essential element, are only possible through a multidisciplinary approach and the comparative analysis of viewpoints and methods.

The maps presented here, in relation with the climatic evolution, illustrate this approach. They propose a reconstruction of the paleoenvironments of the world at two important moments of the past climatic evolution and provide useful data for refining the climatic models and for the examination, from different angles, of the evolution concerning the regions and sites under study. It was in the framework of this geoprospective process that ANDRA (French Agency for the management of nuclear waste) decided to support and follow up the realisation of these documents. As a continuation of the latter the maps of France* and China** have been produced, two examples that should be hopefully followed by other countries.

* La France pendant les deux derniers extrêmes climatiques-Variabilité naturelle des environments. Cartes à 1/1000 000. Coordination: J. Brulhet et N. Petit-Maire, co-édition ANDRA/CNF-INQUA, Paris, 1999.

**China: Environments pendant les deux derniers extrêmes climatiques Cartes à 1/20 000 000. Coordination: B. Y. Yuan, Z.T.Guo et N. Petit-Marie, édition Association

Franco-Chinoise pour la Recherche Scientifique et Technique, Paris, 1998.

\section{Acknowledgments}

We are indebted to Jean Dercourt, President of the CGMW and Perpetual Secretary of the French Academy of Science (Paris), who, upon a suggestion of Nicole Petit-Maire, brought together the most favourable conditions for the realization of this set of maps depicting the world environments during the last two climatic extremes. We express our thanks to ANDRA (French National Agency for Nuclear Waste) for the financial support provided for the compilation and publication of the maps, and thank in particular Bernard Mouroux and Jacques Brulhet of the Geology and Geoproprospective Service of the Scientific Direction of ANDRA, who followed along five years the realization of the project. Thanks are also due to Ibrahim Atalay (Turkey), Guadong Cheng (China), Kevin Hall (Canada), Catherine Kuzucuoglu (France), Anne-Marie Lezine (France), Stephen Porter (USA), Nikolai Romanovskii (Russia), J. Runge (Germany) and Zhuo Zheng (China) for their advice and/or complementary data.

\section{References}

Anderson D.M. \& Webb R.S., 1994 - Ice-age tropics revisited, Nature, 367: 23-24.

Argollo J., 1997 - Escenarios paleohidrológicos y paleoclimáticos en los últimos 30000 años B.P. en el Altiplano boliviano, $6^{\circ}$ Congresso da ABEQUA, Res. Esp., Curitiba: 427-430.

Barreto A., Suguío K., Tatumi S., Nagatomo T. \& Watanabe S., 1997 - O Quaternário tardío no sistema de dunas fixadas no médio rio Sao Francisco (Bahia) datado pelo método da termoluminiscéncia, $6^{\circ}$ Congresso da ABEQUA, Res. Esp., Curitiba: 171-175.

Behling H., 1997 - Studies on Late Quaternary environmental changes in S and SE Brazil with a focus on the history of the Araucaria forests, $6^{\circ} \mathrm{Con}$ gresso da ABEQUA, Res. Esp., Curitiba: 313-316.

Blake W., 1970 - Studies of glacial histories in Arctic Canada I: Pumice, radiocarbon dates, and differential postglacial uplift in the eastern Queen Elizabeth Islands, Canadian Journal of Earth Sciences, 7: 634-664.

Bonnefille R., Roeland J.C. \& Guiot J., 1990 - Temperatures and rainfall estimates for the past 40000 years in equatorial Africa, Nature, 346: $347-$ 349.

Boulton G.S., Peacock J.D. \& Sutherland D.G., 1991 - Quaternary, in Craig, G.Y. (Ed.), Geology of Scotland, Geological Society of London, 612 p.

Bowler J.M., Duller G.A.T., Perret N., Prescott J.R. \& Wyrwoll, K-H. (in press) - Hydrologic changes in monsoonal climates of the Last Glacial Cycle: stratigraphy and luminescence dating of Lake Woods, N.T., Australia, Palaeoclimates: Data and Modelling.

Burn C., 1997 - Cryostratigraphy, paleogeography and climate change during the early Holocene warm interval, western Arctic coast, Canada. Can. J. Earth Sci., 34: 912-925.

Carignano C., 1997 - Caracterización y evolución durante el Cuaternario superior de los ambientes geomorfológicos extraserranos en el noroeste de la provincia de Córdoba, Doctoral thesis, Universidad Nacional de Córdoba, $208 \mathrm{p}$.

Carnahan J.A., 1976 - Natural vegetation. in: Atlas of Australian Resources, 2nd Series, Canberra Department of National Resources.

Clapperton C., 1993 - Quaternary Geology and Geomorphology of South America, Elsevier, New York, 796 p.

Cremaschi, M. \& Van Vliet-Lanoë, B., 1990 -. Traces of frost activity and ice vegetation in Pleistocene loess deposits of Northern Italy. Deep seasonal freezing or permafrost?, Quaternary International, 5: 39-48.

Denton G.H. \& Hughes, T.J. (eds), 1981 - The Last Great Ice Sheets, John Wiley, New York, 484 p.

Denton G.H., Prentice M.L. \& Burckle L.H., 1991 - Cainozoic history of the Antarctic ice sheet, in Tingey R.J. (ed.), The Geology of Antarctica, Oxford Science Publications, $680 \mathrm{p}$.

Derbyshire E., Yafeng S., Jijun Li, Benxing Z., Shijie L. \& Jingtai W., 1991 - Quaternary Glaciation of Tibet : The Geological Evidence, Quaternary Science Reviews, 10: 485-510.

Dyke A.S. \& Prest V.K., 1987 - Late Wisconsin and Holocene History of the Laurentide Ice Sheet, Géographie physique et Quaternaire, 41 (2): 237 263.

Ershov , E.D. (ed.), 1996 - Geocryological map of USSR, scale 1:2 500 000, Moscow State University Press, Moscow, 17 sheets. 
Ershov, E.D. (ed.), 1988-1989 - Geocryology of the USSR, vol. 1-5. Nedra Press, Moscow. (in Russian).

Faustova M.A. \& Velichko, A.A., 1992 - Dynamics of the last glaciation in northern Eurasia, Sveriges Geologiska Undersökning, 81: 113-118.

Forman S.L., Lubinski D., Miller G.H., Snyder J., Matishov G.G., Korsun S. \& Myslivets V., 1995 - Postglacial emergence and distribution of late Weichselian ice-sheet loads in the northern Barents and Kara Seas Russia, Geology, 23: 113-116.

Frenzel B., Pécsi M. \& Velichko A.A. (eds.), 1992 - Atlas of paleoclimates and paleoenvironments of the northern hemisphere, INQUA, Acad. Sci. and Lit. Mainz, Hungar. Acad. Sci., Acad. Sci. USSR; Geogr. Res. Inst. Hungar. Acad. Sci.; Gustav Fischer Verlag, Budapest and Stuttgart,153 p.

Funder S. \& Hansen L., 1996 - The Greenland ice sheet - a model for its culmination and decay during and after the last glacial maximum, Bulletin of the Geological Society of Denmark, 42: 137-152.

Gangloff P., Hétu B., Courchesne F., \& Richard P., 1994: Gélistructure d'un pergélisol würmien sur le Piémont des Pyrénées Atlantiques, Geogr.Phys.Quat. 48, 2: 169-178.

González M., 1981 - Evidencias paleoclimáticas en la Salina del Bebedero, San Luis, $8^{\circ}$ Congreso Geológico Argentino, Actas 3, San Luis: 411-438.

Grindrod J.F., 1988 - The palynology of Holocene mangrove and saltmarsh sediments, particularly in northern Australia, Rev. Palaeobot. Palynol., 55: $229-245$.

Grosswald M.G., 1980 - Late Weichselian ice sheets of northern Eurasia, Quaternary Research, 13: 1-32.

Guilderson T.,Fairbanks R. \& Rubenstone J.L., 1994 - Tropical temperature variations since 20,000 years ago: Modulating interhemispheric climate change, Science, 263: 663-665.

Hamilton T.D. \& Thorson R.M., 1983 - The Cordilleran Ice Sheet in Alaska, in: Porter, S.C. (ed.), Late-Quaternary Environments of the United States, Vol. 1, The Late Pleistocene, Longman, 407 p.

Haxeltine A., Prentice I.C. \& Creswell I.D. (in press) - A coupled carbon and water flux model to predict vegetation structure, Journal of Vegetation Science.

Heaton T.H.E., Talma A.S. \& Vogel J.C., 1986 - Dissolved gas palaeotemperatures and ${ }^{18} \mathrm{O}$ variations derived from groundwater near Uitenhage, South Africa, Quaternary Res., 25: 79-88.

Hebbeln D., Dokken T., Andersen E.S., Hald M. \& Elverhoi A., 1994 - Moisture supply for northern ice-sheet growth during the Last Glacial Maximum, Nature, 370: 357-360.

Helmens K. \& Van der Hammen T., 1994 - The Pliocene and Quaternary of the High Plain of Bogotá (Colombia): A history of tectonic uplift, basin development and climatic change, Quaternary Res., 21: 41-62.

Hutson W.H. \& Prell W., 1980 - A paleoecological transfer function, FI-2, for Indian Ocean planktonic foraminifera, J. Palaeontol., 54: 381-391

Imbrie J. \& Kipp N. G., 1971 - A new micropaleontological method for quantitative paleoclimatology: Application to a late Pleistocene Caribbean core, in Turekian K. K. (ed.), The late Cenozoic glacial ages, Yale Univ. Press, New Haven: 71-181.

Ingólfsson O., 1991 - A review of the Late Weichselian and early Holocene glacial and environmental history of Iceland, in Maizels, J.K. (ed.), Environmental Change in Iceland : Past and Present, Kluwer Academic Publishers, London: 13-29.

Iriondo M., 1995 - Patagonia extraandina y Tierra del Fuego, in: Argollo J. \& Mourguiart Ph. (Eds.), Climas Cuaternarios en América del Sur, ORSTOM, La Paz: 339-344.

Iriondo M., 1997 - Models of loess and loessoids in the Upper Quaternary of South America, Journ. South American Earth Sci., 10 (1): 71-79.

Iriondo M., 1998 - Climatic changes in the South American plains. Records of a continent-scale oscillation, Quaternary International, 57/58: 93-112.

Iriondo M. \& García N., 1993 - Climatic variations in the Argentine plains during the last 18,000 years, Palaeogeogr. Palaeoclimatol. Palaeoecol., 101:209-220.

Iriondo M. \& Krohling D., 1996 - El Sistema Eólico Pampeano, Com. Museo de Ciencias Naturales "Florentino Ameghino", Santa Fe, Argentina, 5(1): $1-68$.

Kaiser K., 1969 - The climate of Europe during the Quaternay Ice Age, in Wrigt H.E. (ed.), Quaternary geology and climate, INQUA publ., Nat Acad. Press, 16, Washington D.C.: 10-37.

Karlén W., 1998 - Climate variations and the enhanced greenhouse effect, Ambio, 27: 270-274.

Kealhofer L. \& Penny D. (in press) - Fourteen thousand years of vegetation change in northeast Thailand, Review of Palaeobotany and Palynology.

Khobzy J., 1981 - Los campos de dunas del norte de Colombia y de los Llanos de la Orinoquía (Colombia y Venezuela), Revista CIAF, 6(1-3), Bogotá: 257-292.
King L. \& Seppälä M., 1987 - Permafrost thickness and distribution in Finnish Lapland - results of geoelectrical soundings, Polarforschung, 57: 127-147.

Kipp N. G., 1976 - New transfer function for estimating past sea-surface conditions from seabed distribution of planktonic foraminiferal assemblages in the North Atlantic, in Cline R. M. \& Hays J. D. (eds.), Investigation of Southern Ocean Paleoceanography and Paleoclimatology, Geol. Soc. Amer. Mem., 145: 3-42.

Kong Z. C., Du N.Q., Sun C.Q. \& Zhang J.H., 1994 - Study on the vegetation and natural environment based on pollen analysis in Bailiandon ruins, in Zhong G.X. (Ed.), Proceedings of China-Japan international conference on relationship between palaeoanthropology and prehistoric culture, Beijing, International Broadcast Press of China: 176-210. (in Chinese).

Kudryavtsev, V.A. (ed.), 1978 - General Geocryology, Moscow State University Press, Moscow, 463 p. (in Russian).

Kuhle M., 1988 - Geomorphological findings on the build-up of Pleistocene glaciation in southern Tibet and the problem of inland ice, GeoJournal, 17: 457-512.

Landvik J.Y., Mangerud J. \& Salvigsen O., 1988 - Glacial history and permafrost in the Svalbard area, 5th Intern.Conf.Permafrost, Trondheim, Apir Pub.: 194-198.

Landvik J.Y., Bondevik S., Elverhøi A., Fjeldskaar W., Mangerud J., Salvigsen O., Siegert M.J., Svendsen J-I. \& Vorren T.O., 1998 - The last glacial maximum of Svalbard and the Barents Sea area : ice sheet extent and configuration, Quaternary Science Reviews, 17: 43-75.

Ledru M., Salgado-Labouriau M. \& Lorscheitter M., 1997 - Holocene vegetation in Southern and Central Brazil, $6^{\circ}$ Congresso da ABEQUA, Res Exp., Curitiba: $451-454$

Leroy-Ladurie E., 1984 - Histoire du Climat depuis l'An Mil, Champs, Flammarion, no. 108 .

Levitus S., 1982 - Climatological Atlas of the World Ocean, NOAA Prof. Pap., 13, $173 \mathrm{p}$.

Lézine A.M., 1998 - Le Yémen désertique : une ancienne région humide, Pour la Science, 250: 54-59.

Lichte M., 1991 - Cyclic features in the Quaternary development of SE Brazil, $3^{\circ}$ Congresso da ABEQUA, Publ. Esp., 1, Belo Horizonte: 33-35.

Livingstone D.A., 1971 - A 22 000-year pollen record from the plateau of Zambia, Limnology and Oceanography, 16: 349-356.

Maarleveld G., 1976 - Periglacial phenomena and the mean annual temperature during the Last Glacial Time in the Netherlands, Biuletyn Peryglacjalny, 26: $57-78$

Mahaney W.C., 1990 - Ice on the Equator, Caston, Ellison Bay, 386 p.

Maley J., 1993 - The climatic and vegetational history of the equatorial regions of Africa during the Upper Quaternary, in Shaw T., Sinclair P; Barsey A. \& Okpoko A. (Eds.), The Achaeology of Africa, Routledge, London: 43-52.

Markgraf V., Dodson J.R., Kershaw A.P., McGlone M.S. \& Nicholls, N., 1992 - Evolution of late Pleistocene and Holocene climates in the circumSouth Pacific land areas. Climate Dynamics, 6: 193-211.

McGlone M.S., 1988 - New Zealand, in Huntley B. \& Webb III T. (eds.), Vegetation History, 7, Kluwer Academic Publishers, Dordrecht.

Mears B., 1981: Periglacial wedges and the Late Pleistocene Environment of Wyoming's Intermontane Basins, Quaternary Res., 15: 171-198.

Meese D.A., Gow A.J., Grootes P., et al., 1994 - The accumulation record from the GUSP2 core as an indicator of climatic change throughout the Holocene, Science, 266: 1680-1682.

Moss P.T. \& Kershaw A.P. (in review) - The last glacial cycle from the humid tropics of northeastern Australia: comparison of terrestrial and marine records, Palaeogeogr. Palaeoclimatol. Palaeoecol.

Murton J.B. \& French H.M., 1993 - Thaw modification of frost-fissure wedges, Richards Island, Pleistocene Mackensie Delta, Western Arctic Canada. Journal of Quaternary Sci., 8 (3): 185-196.

National Geographic, 1999 - Diversity of Life, inlay map, scale 1:54 109 440, February 1999, 195, 2

Pachur J.J. \& Kröpelin S., 1987 - Paleoclimatic implications of Late Quaternary lacustrine sediments in Western Nubia, Sudan, Quaternary Res. 36: $257-276$.

Pachur H.J. \& Altmann N., 1997 - The Quaternary Holocene ca 8000 B.P. in Schandlemeier \& Reynolds (eds.), Paleographic-Paleotectonic Atlas of North-Eastern Africa, Arabia and adjacent areas. Explanatory Notes, Balkema, Rotterdam: 111-125

Partridge T.C., Scott L. \& Hamilton J.E., 1998 - Synthetic reconstructions of southern African environments during the Last Glacial Maximum (21-18 kyr) and the Holocene Altithermal (8-6 kyr), Quaternary International, 57/58: 207-214.

Payette \& Morneau C., 1993 - Holocene relict woodlands at the Eastern Canadian Treeline, Quaternary Res., 39: 84-89. 
Petit-Maire N., 1994 - Natural variability of the Asian, Indian and African monsoons over the last $130 \mathrm{ka}$, in Desbois M. \& Désalmand F. (eds.), Global precipitations and climate change, Heidelberg, Springer Verlag, NATO ASI Series, I-26: 3-26.

Petit-Maire N., Sanlaville P. \& Zhong Wei Y., 1994 - Changements globaux et paléomoussons: la zone de transition afro-asiatique au cours des derniers 140000 ans, Géochronique, 50: 16-19.

Petit-Maire N. \& Guo Z.T., 1996 - Mise en évidence de variations climatiques holocènes rapides, en phase dans les déserts actuels de Chine et du Nord de l'Afrique, C. R. Acad. Sci., Paris (IIa), 322: 847-851

Petit-Maire N. \& Bryson P., 1998 - Holocene climatic change and Man in the Sahara, in Demarée G., Alexandre J. \& De Dapper M. (eds.), Tropical Climatology, Meteorology and Hydrology, Royal Meteorological Institute/Académie Royale des Sciences d'Outre-Mer, Bruxelles: 51-67.

Pewe T., 1983 - The periglacial environment in North America during Wisconsin time, in Wright H.E. \& Porter S.C. (ed.), Late Quaternary environments in the United States, vol 1., Univ. Minnesota Press, Minneapolis: $157-189$.

Pflaumann U., Duprat J., Pujol C. \& Labeyrie, L.D., 1996 - SIMMAX: A modern analog technique to deduce Atlantic sea surface temperatures from planktonic foraminifera in deep-sea sediments, Paleoceanogr., 11: $15-35$.

Porter S.C., 1975 - Equilibrium line of late Quaternary glaciers in the Southern Alps New Zealand, Quaternary Res., 5: 27-48.

Porter S., 1988 - Landscape of the last Ice Age in North America, in: Carlisle R.C. (Ed.), Americans before Columbus: ice age origins, Ethnology Monographs, vol.12, Univ. Pittsburg: 1-24.

Porter S.C., Pierce K.L. \& Hamilton T.D., 1983 - Late Wisconsin Mountain Glaciation in the Western United States, in Porter S.C. (ed.), Late-Quaternary Environments of the United States. Volume 1, The Late Pleistocene, Longman, $407 \mathrm{p}$

Prell W. \& Kutzbach J., 1987 - Monsoon variability over the past 150,000 years, J. Geophys. Res., 92: 8411-8425.

Richard P., 1995 - le couvert végétal du Québec-Labrador il y a 6000 ans B.P., Essai. Geogr.Phys.Quat., 49, 1: 117-140.

Rinaldi M., Rull V. \& Schubert C., 1990 - Análisis paleoecológico de una turbera en la Gran Sabana (Santa Cruz de Mapauri), Venezuela: Resultados preliminares, Acta Científica Venezolana, 41, Caracas: 66-68.

Rind D. \& Peteet D., 1985 - Terrestrial conditions at the last glacial maximum and CLIMAP surface temperature estimations: are they consistent? Quaternary. Res., 24: 1-22.

Roa P., 1979 - Estudio de los médanos de los Llanos Centrales de Venezuela: Evidencias de un clima desértico, Acta Biológica Venezolana, 10, Caracas: 19-49.

Romanovskii, N.N. 1993 - Bases of the Lithosphere Cryogenesis, Moscow State University Press, Moscow, 336 p. (In Russian).

Rosqvist G., 1990 - Quaternary glaciations in Africa,, Quaternary Science Reviews, 9:: 281-297.

Runge J. \& Runge F., 1995 - Late Quaternary palaeoenvironmental conditions in Eastern Zaire (Kivu) deduced from remote sensing, morphopedological and sedimentological studies (Phytoliths, Pollen, ${ }^{14} \mathrm{C}$ data), Proceedings of 2nd International Palynology Conference, 1995, Tervuren.

Sanlaville P., 1994 - L'évolution de la péninsule Arabique depuis le Pléistocène supérieur, Annales de Géographie, Beyrouth,15:49-60.

Santos J., 1993 - O Pantanal Setentrional e os campos de dunas da Amazonia Occidental, International Symposium on the Quaternary in Amazonia, Resumos, Universidade do Amazonas/INPA/UNESCO:110-111.

Sarnthein M., 1978 - Sand deserts during glacial maximum and climatic optimum, Nature, 272: 43-46.

Sarnthein M., Jansen E., Weinelt M., Arnold M., Duplessy J.C., Erlenkeuser H., Flatøy A., Johannessen G., Jung S., Koc N., Labeyrie L., Maslin M., Pflaumann U. \& Schulz H., 1995 - Variations in Atlantic surface paleoceanography, $50^{\circ}-80^{\circ} \mathrm{N}$ : A time-slice record of the last 30,000 years, Paleoceanography, 10/6: 1063-1094.

Scott L., 1993 - Palynological evidence for Late Quaternary warming episodes in Southern Africa, Palaeogeogr. Palaeoclimatol. Palaeoecol., 101: 229-235

Sejrup H.P., Haflidason H., Aarseth I., King E., Forsberg C.F., Long. D. \& Rokoengen K., 1994 - Late Weichselian glaciation history of the northern North Sea. Boreas, 23: 1-13.

Shi Y. (Ed.), 1988 - Map of snow, ice and frozen ground in China, scale 1:4 000 000, with explantory Notes, China Cartographic Publ., Beijing.

Siffedine A., 1991 - La sédimentation en région tropicale humide (Carajas, Amazonie, Brésil). Relation avec les modifications de l'environnement climatique au cours des 60,000 dernières années. Thèse. Mus. Nat. Hist. Nat., Paris, 119 p.
Sirocko F., Sarnthein M., Erlenkeuser H., Lange H., Arnold M. \& Duplessy J.C., 1993 - Century-scale events in monsoonal climate over the past 24,000 years, Nature, 364: 322-324.

Soons J.M., 1979 - Late Quaternary environments in the central South Island of New Zealand, New Zealand Geographer, 35: 16-23.

Soons J.M. \& Price L.W., 1990 - Periglacial phenomena in New Zealand, Permafrost and Periglacial Processes, 1: 134-139.

Specht R.L., 1970 - Vegetation, in G,W. Leeper (ed.), The Australian Environment, 4th edition, Melbourne: CSIRO and Melbourne University Press: 44-67.

Stager J.C., 1988 - Environmental Changes at Lake Cheshi, Zambia, since 40,000 years B.P., Quaternary Res., 29: 54-65.

Stine S. \& Stine M., 1990 - A record from lake Cardiel, climatic change in Southern South America, Nature, 345: 705-708.

Stuijts I., Newsome J.C. \& Flenley J.R., 1988 - Evidence for late Quaternary vegetational change in the Sumatran and Javan highlands, Review of Palaeobot. Palynol., 55: 207-216.

Stute M. \& Talma A.S. - Glacial temperatures and moisture transport regimes reconstructed from noble gases and ${ }^{18} \mathrm{O}$, Stampriet aquifer, Namibia: Proceedings of International Symposium on Isotope Techniques in the Study of Past and Current Environmental Changes in the Hydrosphere and the Atmosphere, Vienna, International Atomic Energy Agency (in press).

Talbot M., 1984 - Late Pleistocene rainfall and dune building in the Sahel, Palaeoecology of Africa, 16: 203-214.

Talma A.S. \& Vogel J.C., 1992 - Late Quaternary palaeotemperatures derived from a speleothem from Cango Caves, Cape Province, South Africa, Quaternary Res., 37: 203-213.

V.V., Danilova N.S. \& Sukhodolskaya L.A., 1981 - Historical development of permafrost at the territory of the USSR and methods of its study, in: History of development of permafrost of the Eurasia (on the example of separate regions), Nauka Press, Moscow: 41-60. (in Russian).

Van der Kaars W.A., 1991 - Palynology of eastern Indonesian marine pistoncores. A late Quaternary vegetational and climatic record for Australasia, Palaeogeogr. Palaeoclimatol. Palaeoecol., 85: 239-302.

Van der Kaars W.A. \& Dam M.A.C., 1995 - 135,000-year record of vegetational and climatic change from Bandung area, West-Java, Indonesia, Palaeogeogr. Palaeoclimatol., Palaeoecol., 117: 55-72.

Van Tatenhove, F.G.M., 1995 - The dynamics of Holocene deglaciation in west Greenland with emphasis on recent ice-marginal processe, CIPData Koninklijke Bibliotheek, Den Haag, 202 p.

Vandenberghe J. \& Kasse C, 1993 - Periodic ice-wedge formation and weichselian cold-climate floodplain sedimentation in the Netherlands, 6th Internat. .Permafrost Conf., Beijing (5-9 July): 643-647.

Vandenberghe, J. \& Pissart A., 1993 - Permafrost changes in Europe during the Last Glacial, Permafrost and Periglacial Processes, 4: 121-135.

Velichko, A.A. (ed.), 1984 - Late Quaternary environment of the Soviet Union, University of Minnesota Press, Minneapolis, 327 p.

Velichko A.A., Bogucki A.B.,Morozova T.D., Udarstev, V.P., Khalcheva T.A. \& Tsatskin A.I., 1984 - Periglacial Landscapes of the East European plain, in: Late Quaternary Environments of the Soviet Union, A.Velichko publ.: 95-118.

Velichko A.A., Isayeva L.L., Makeyev V.M., Matishov G.G. \& Faustova M.A., 1984 - in Velichko, A.A. (ed.) Late Quaternary Environments of the Soviet Union, Longman, $327 \mathrm{p}$.

Vogel J.C., 1987 - Chronological framework for palaeoclimatic events in the Namib, NPRL Research Report CFIS, 145, Council for Scientific and Industrial Research, Pretoria, $20 \mathrm{p}$.

Washburn A.L., 1979 - Geocryology. A survey of periglacial processes and environment, Arnold Publ. London, 406 p.

Washburn A.L., 1980 - Permafrost features as evidence of climate change, Earth Sci. Rev., 15: 327-402.

Weinelt M., Sarnthein M., Pflaumann U., Schulz H. \& Jung S., 1996 - Icefree Nordic Seas during the Last Glacial Maximum? Potential sites of deepwater formation, Paleoclimates, Data and Modelling, 1: 283-309.

Winkler M.G. \& Wang P.K., 1993 - The Late-Quaternary vegetation and climate of China, in Wright H.E. Jr. et al. (eds.), Global Climates since the Last Glacial Maximum, University of Minnesota Press, Minneapolis: 221-264.

Wirrmann D., Mourguiart Ph. \& Oliveira Almeida L., 1988 - Holocene sedimentology and ostracod distribution in lake Titicaca - Paleohydrological interpretations, Quaternary of S. America \& Antarctic Pen., 6: 89-128. 
Zheng Z., Yuan B.Y. \& Petit-Maire N., 1998 - Paleoenvironments in China during the Last Glacial Maximum and the Holocene Optimum, Episodes, 21, 3: 152-158.

Zoltai S., 1995 - Permafrost distribution in peatlands of West-central Canada during the Holocene warm period 6000 B.P., Geogr.Phys.Quat. 49,1: 4554.

\section{Authorship}

\section{Scientific coordinators:}

Nicole Petit-Maire and Philippe Bouysse

\section{Regional and or thematic authors: (in alphabetical order)}

Jacques-Louis de Beaulieu, Laboratoire de Botanique Historique et Palynologie, Faculté des Sciences et Techniques de StJérôme, Marseille (France). e-mail: Jacques-louis.debeaulieu@lbhp.u-3mrs.fr

Geoffrey Boulton, Institute of Geology and Geophysics, The University of Edinburgh, Grant Institute, Edimbourg (Grande Bretagne).e-mail: g.boulton@glg.ed.ac.uk

Zhengtang Guo, Institute of Geology, Chinese Academy of Sciences, Beijing (China).e-mail: ztguo@mimi.cnc.ac.cn

Martin Iriondo, Universidad Nacional de Entre Rios, Paran. (Argentina).e-mail: rniriond@alpha.arcride.edu.ar

Peter Kershaw, Department of Geography and Environmental Science, Monash University, Clayton (Victoria, Australia). e-mail: peter.kershaw@arts.monash.edu.au

Olga Lisitsyna, Geocryology Department, Moscow State University, Moscou (Russia).e-mail: olis@glasnet.ru

Tim Partridge, Climatology Research Group, University of the Witwatersrand, Johannesbourg (Republic of South Africa). e-mail: 141tcp@cosmos.wits.ac.za

Uwe Pflaumann (up@gpi.uni-kiel.de) and Michael SARNThein (ms@gpi.uni-kiel.de), Geologisch-Paläontologisches Institut und Museum der Universität Kiel, Kiel (Germany).

Hartmut Schulz, Institut für Ostseeforschung Warnemünde, Rostock-Warnemünde (Germany)

Jane Soons, Department of Geography, University of Canterbury, Christchurch (New Zealand)

Brigitte Van Vliet-Lanoë, Sédimentologie et Géodynamique, CNRS/Université de Lille 1, Villeneuve d'Ascq (France). email:Brigitte.van-Vliet-Lanoe@univ-lille1.fr

Baoyin Yuan, Institute of Geology, Chinese Academy of Sciences, Beijing (China). e-mail: global@mimi.cnc.ac.cn

Martin van der Zijp, Netherland Institute for Sea Research, Den Burg-Texel (Netherland). e-mail: zijp@nioz.nl

\begin{abstract}
N. Petit-Maire, emeritus Director of Research at the Centre National de la Recherche Scientifique (CNRS), France, served as Vice-President of the IUGS (1989-1996) and President of the French INQUA Committee (1996-2000). She is President of the Scientific Committee of the Centre International pour la Formation et les Echanges Géologiques and member of the Académie des Sciences d'Outre Mer (Paris). She has worked in paleoenvironments over the last 25 years focusing particularly on world deserts and was one of the first Quaternarists to consider together multidisciplinary data, especially in the hyperarid areas of the Old World.
\end{abstract}

P. Bouysse is Secretary General of the Commission for the Geological Map of the World (CGMW) since 1991, member of the Bureau of the French Geological Society and the Editorial Board of Géochronique. He joined the Bureau de Recherches Géologiques et Minières (BRGMFrench Geological Survey) in 1962, where he initiated and developed the marine geology activities. He was scientific advisor of the BRGM Marine Geology and Geology departments until 1990. As main compiler, he published in October 2000 the 2 nd edition of the Geological Map of the World.
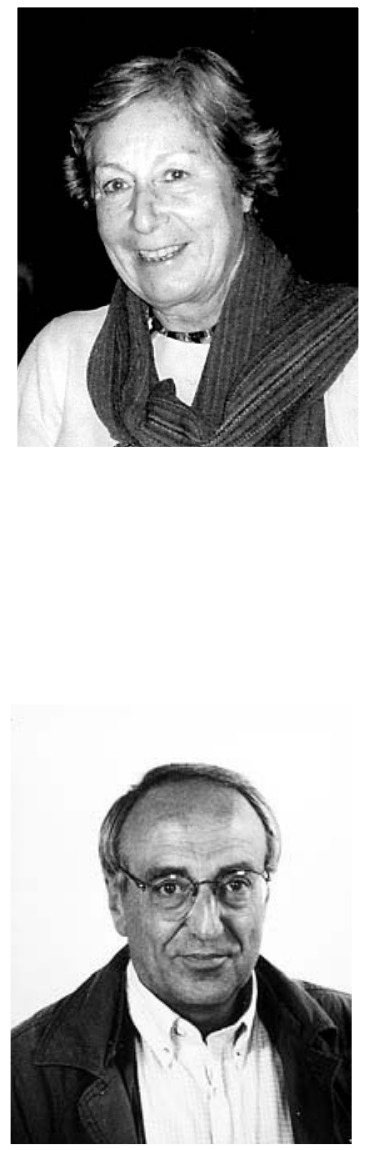

\section{COMMISSION FOR THE GEOLOGICAL MAP OF THE WORLD (CGMW)}

The CGMW, one of the oldest international organisations in geoscience, was created in 1881 during the 2nd International Geological Congress (IGC) in Bologna. It is a non-profit scientific and pedagogic body governed by French law. The CGMW' aims are to promote, coordinate and publish synthetic Earth sciences maps, at small scale, of continental and/or oceanic areas of the World. It is one of the Commissions of the IGC and is affiliated to the International Union of Geological Sciences (IUGS) since the creation of the latter in 1961. As an active member of scientific unions and an international non-governmental organization, CGMW is recognized by UNESCO as an NGO of category A and is thus entitled to receive funds from this organisation.

Geological Surveys (or organizations responsible for national geological mapping) of all countries and territories of the World are statutory members of the CGMW. Other organizations interested are allowed to join the CGMW as Associated Members. A score of widely recognized scientists coming from different regions of the world, appointed to represent their respective continent or sub-continent at CGMW or to head the different Thematic Sub-commissions, conform the CGMW Bureau under the direction of the President and the Secretary General of the Commission whose headquarters are in Paris.

CGMWís General Assemblies are held every two years, alternatively at UNESCO headquarters in Paris, and within the framework of the International Geological Congress. These meetings are the occasion to examine the outcome of current cartographic projects and to define the trends of future programmes. 